\title{
Enrique Dussel: contribuições para a crítica ética e radical nos Estudos Organizacionais
}

\author{
Enrique Dussel: contribuciones a la crítica ética y radical en los Estudios Organizacionales \\ Enrique Dussel: contributions to an ethical and radical critique in Organization Studies \\ Maria Ceci Misoczky ${ }^{1}$ \\ Universidade Federal do Rio Grande do Sul / Escola de Administração, Programa de Pós-Graduação em Administração, Porto Alegre - RS, Brasil \\ Guilherme Dornelas Camara ${ }^{2}$ \\ Universidade Federal do Rio Grande do Sul / Escola de Administração, Porto Alegre - RS, Brasil
}

\begin{abstract}
Resumo
Nesse ensaio, vinculamo-nos ao esforço que alguns autores vêm realizando de elaborar uma crítica ética e radical nos Estudos Organizacionais (EO) para libertar pelo menos algumas de suas partes da colonização pelo management. Nesse sentido, tomamos como referência as proposições criticamente situadas na América Latina da Filosofia da Libertação (FL) elaboradas por Enrique Dussel. Na primeira parte, apresentamos uma visão abrangente desta vasta obra que se justifica pela apropriação parcial e mesmo incoerente que vem sendo realizada nos EO. Na segunda parte, discutimos algumas apropriações que vêm sendo feitas por autores vinculados aos EO no contexto latino-americano, com destaque para o brasileiro. Esse diálogo crítico é indispensável para que se libere o caminho para que a FL de Dussel contribua para o exercício de uma crítica que negue, lado a lado com as vítimas, a legitimidade de um sistema que explora e oprime e que, simultaneamente, se comprometa com a afirmação da vida humana em comunidade e, portanto, com a práxis da libertação.
\end{abstract}

Palavras-chave: Filosofia da libertação. Práxis da libertação. Crítica. Enrique Dussel. Ética.

\section{Resumen}

En este ensayo, nos vinculamos al esfuerzo que algunos autores han llevado a cabo para elaborar una crítica ética y radical en los Estudios Organizacionales (EO) para libertar al menos algunas de sus partes de la colonización por el management. En este sentido, nos referimos a las proposiciones críticamente situadas en América Latina de la Filosofía de la Liberación (FL) elaboradas por Enrique Dussel. En la primera parte, presentamos una mirada abarcadora de esta gran obra que se justifica a partir de la apropiación parcial e incluso incoherente que ha sido realizada en los EO. En la segunda parte, discutimos algunas apropiaciones que se han hecho por autores vinculados a los EO en el contexto latinoamericano, con énfasis en el brasileño. Este diálogo crítico es indispensable para la liberación del camino para que la FL de Dussel contribuya al ejercicio de una crítica que niegue, lado a lado con las víctimas, la legitimidad de un

Artigo submetido em 31 de janeiro de 2014 e aceito para publicação em 16 de julho de 2014.

\section{DOI: http://dx.doi.org/10.1590/1679-395115875}

${ }^{1}$ Docente e pesquisadora da Escola de Administração e do Programa de Pós-Graduação em Administração da UFRGS; Coordenadora da área de Administração Púbica e Social; Coordenadora do Grupo de Pesquisa Organização e Práxis Libertadora; Membro do Coletivo Editorial da Revista Brasileira de Estudos Latino-Americanos - REBELA. Endereço: Rua Washington Luiz, 855 - sala 427 Centro Histórico, CEP 90010-460, Porto Alegre-RS, Brasil. E-mail: maria.ceci@ufrgs.br

2 Docente e pesquisador da Escola de Administração da UFRGS; Membro do Grupo de Pesquisa Organização e Práxis Libertadora. Endereço: Rua Washington Luiz, 855 - sala 445 - Centro Histórico, CEP 90010-460, Porto Alegre-RS, Brasil. E-mail: guilherme.dornelas@ufrgs.br 
sistema que explota y oprime y que, al mismo tiempo, se comprometa con la afirmación de la vida humana en comunidad y, por lo tanto, con la praxis de la liberación.

Palabras clave: Filosofía de la liberación. Praxis de la liberación. Crítica. Enrique Dussel. Ética.

\begin{abstract}
In this essay, we connect ourselves with the efforts provided by some authors to elaborate a radical and ethical critique in the field of Organization Studies (OS) liberated, at least in some parts, from the colonization by management. In this direction, we take as reference the propositions of Enrique Dussel's Philosophy of Liberation (PL), which are critically situated in Latin America. In the first part, we present a comprehensive overview of this vast oeuvre, justified by the partial and even incoherent appropriation that has been happening in OS. In the second part, we discuss some of these appropriations considering some Latin American authors of the OS field, highlighting specially the Brazilian context. This critical dialogue is indispensable to liberate the path for the contribution of Dussel's PL to the exercise of a critique that negates, side by side with the victims, the legitimacy of a system that explores and oppresses, and that, simultaneously, gets involved with the affirmation of human life in community, and therefore, with the praxis of liberation.
\end{abstract}

Keywords: Philosophy of Liberation. Praxis of Liberation. Critique. Enrique Dussel. Block of the Oppressed.

\title{
Introdução
}

Iniciamos este ensaio esclarecendo o significado de crítica adotado. Seguindo Dussel (2001, p. 285) e a Teoria Crítica fundada nas proposições de Adorno e Horkheimer (1985), entendemos que a crítica precisa "cumprir com duas condições: ser negativa e material". A negatividade é o "não-poder-viver dos oprimidos, explorados, das vítimas". Além disso, essa "negação originária" deve situar-se no nível da materialidade, isto é, "no conteúdo da práxis que se refere à produção, reprodução e desenvolvimento da vida humana", à sua corporalidade e ao seu existir em comunidade. No entanto, esses dois critérios de demarcação não são suficientes. É preciso, além da posição teórica negativo-material, colocar-se 'efetiva e praticamente 'junto' à vítima e não apenas em posição observacional participativa [...], mas como o co-militante que entra no horizonte prático da vítima (negatividade-material) a quem decide servir por meio de um programa de pesquisa científico-crítico (explicativo das 'causas' da sua negatividade)" (DUSSEL, 2001, p. 286). Esse sentido da práxis é inspirado na concepção de Marx (2005), segundo a qual a crítica não se refere apenas ao pensamento, mas também ao mundo objetivo e sempre está voltada para transformá-lo, ou seja, trata-se de uma prática-crítica-revolucionária.

Claro está que o exercício de um programa científico desde o "colocar o próprio corpo [...] ao lado ou junto à vítima" apresenta enormes dificuldades no campo dos Estudos Organizacionais (EOs). Nesse sentido, nos vinculamos ao esforço que alguns autores vêm realizando para "libertar pelo menos parte dos Estudos Organizacionais, inclusive dos Estudos Críticos em Administração, da hegemonia do management, abrindo possibilidades para múltiplos diálogos interdisciplinares e interculturais [...] de modo a dar conta do estudo da organização das lutas sociais" (MISOCZKY, 2011, p. 360).

Feitos esses esclarecimentos, podemos introduzir as partes que compõem esse ensaio. Na primeira, realizamos uma apresentação da Filosofia da Libertação (FL) desenvolvida por Enrique Dussel. Como ele mesmo esclarece, e sem pretender representar um movimento mais amplo, Dussel (2004a, p. 143) pratica, desde 1969, uma FL que "parte de uma realidade regional própria":

[...] a pobreza crescente da maioria da população latino-americana; a vigência de um capitalismo dependente que transfere valor ao capitalismo central; a tomada de consciência da impossibilidade de uma filosofia autônoma nestas circunstâncias; a existência de tipos de opressão que exigem não apenas uma filosofia da "liberdade", mas uma filosofia da 
"libertação" (como ação, como práxis cujo ponto de partida é a opressão, e o ponto de chegada a indicada liberdade) [...].

Essa apresentação busca, apesar da síntese necessária devido ao espaço disponível, propiciar uma visão abrangente e coerente desta vasta obra e se justifica face à apropriação parcial e, mesmo, incoerente que vem sendo realizada nos EOs, como se verá na segunda parte. A apresentação se constitui em um exercício livre de história intelectual por reconhecer, como diz Altamirano (1997, p. 9), que a história intelectual "é praticada de muitas maneiras e não possui em seu âmbito uma linguagem teórica ou modos de proceder que funcionem como modelos obrigatórios nem para analisar, nem para interpretar seus objetos". Nesse sentido e sem pretender entrar nas disputas que ocorrem nesse espaço disciplinar (ver, p. ex., SILVA, 2002; SILVA, 2009), adotamos o seguinte procedimento: valorizar na trajetória de Dussel sua história pessoal em articulação com suas formulações, seguindo uma linha do tempo e de eventos indicada em textos autobiográficos (DUSSEL 1995a; 1998; 2008; 2011a; 2012a). Na segunda parte, discutimos algumas apropriações que vêm sendo feitas por autores vinculados aos EOs no contexto latino-americano, com destaque para o brasileiro. Esse diálogo crítico é indispensável para que se libere o caminho para que a FL de Enrique Dussel contribua para o exercício nos EOs de uma crítica que negue, lado a lado com as vítimas, a validade do sistema que explora e oprime e que, simultaneamente, se envolva com a afirmação da vida humana em comunidade e, portanto, com a práxis da libertação. Optamos por não terminar este texto de modo conclusivo. Dado seu caráter ensaístico, deixamos apenas indicativos de possibilidades como finalização.

\section{A trajetória de Enrique Dussel e de sua filosofia: da hermenêutica à libertação}

Dussel (1998, p. 14) descreve seu local de nascimento (La Paz, na Província argentina de Mendoza) como um "povoado a partir do qual García Márquez poderia ter escrito de novo Cem anos de solidão". Seu pai "de quem era uma honra ser filho" - era um médico positivista e agnóstico "adorado pelo povo a quem se dedicava com generosidade", tendo fundado uma "clínica social do povo". Sua mãe era uma militante social de quem os três filhos herdaram o "espírito de compromisso social, político e crítico". Depois de uma passagem por Buenos Aires, para onde a família se mudou durante a II Guerra porque seu pai havia sido despedido do emprego na ferrovia devido à sua origem alemã, retornam à Mendoza, mas para a capital provincial de mesmo nome. Se inicia, então, um período de "profundas experiências juvenis", "uma época de formação acelerada de uma personalidade prática, social, política, intelectual": a militância na Ação Católica, "uma profunda experiência de conversão à responsabilidade com o Outro" em visitas aos hospitais de crianças com deficiência; a participação na fundação da Federação Universitária do Oeste; a presidência do Centro Estudantil de Filosofia e Letras; as greves e a prisão pela participação nos movimentos estudantis contra Perón em 1954 (DUSSEL, 1998, p. 15).

No curso de Filosofia, na Universidade Nacional de Cuyo, lia "Platão e Aristóteles em grego, Santo Agostinho ou Tomás em latim, Descartes ou Leibniz em francês, Scheler ou Heidegger em alemão" e, "contra o fascismo de direita" de alguns professores, tornou-se "seguidor democrático" de Jacques Maritain e Emmanuel Mourier. Terminado o curso, recebe, em 1957, uma bolsa para continuar os estudos em Madri: "a mentalidade 'colonial' latino-americana me exigia, me condicionava quase, a realizar a experiência europeia” (DUSSEL, 1998, p. 15).

Nessa viagem, ele se descobre latino-americano. Surge aí a quase obsessão, a "angústia existencial de conhecer-se" e de buscar respostas para as perguntas sobre "quem somos nós culturalmente?", "qual é nossa identidade histórica?" (DUSSEL, 2012, p. 29).

Na universidade franquista, constata que essa não era superior à de Mendoza. Após fazer os cursos exigidos, defendeu o trabalho de qualificação intitulado Problemática del bien común en el pensar griego hasta Aristóteles. Concluído o curso, vai de carona a Israel. Após uma longa viagem, fica um mês trabalhando em uma cooperativa árabe: "a violência da pobreza, o rude trabalho manual, o calor do deserto - experiências 
fortes, definitivas, profundas, místicas, carnais ...”. Retornando a Madri, acelera o doutorado (para voltar a Israel) e defende a tese La problemática del bien común, em 1959 (DUSSEL, 1998, p. 16).

Novamente em Israel, desta vez por dois anos:

[...] carpinteiro da construção em Nazaré, pescador no lago Tiberiades no kibutz Ginosar, peregrino em toda Palestina [...], estudante de hebraico [...], a vida em comunidade entre os companheiros árabes junto a Paul Gauthier ${ }^{3}$, abriram a minha mente, meu espírito, minha carne, para um projeto novamente inesperado. Agora não era apenas a América Latina; agora eram os "pobres" (obsessão de Paul Gauthier), os oprimidos, os miseráveis de meu continente distante. Contando-lhe a história latino-americana em uma daquelas noites frescas em nossa pobre barraca da cooperativa de construção feita para trabalhadores árabes que construíam suas próprias casas em Nazaré, me entusiasmei com um Pizarro que conquistava o império inca com poucos homens. Gauthier, olhando-me nos olhos perguntou: quem eram naquela ocasião os pobres, Pizarro ou os índios? Naquela noite, com uma vela iluminando, escrevi a meu amigo historiador de Mendoza - Esteban Fontana: "Algum dia deveremos escrever a História da América Latina do outro lado, desde baixo, desde os oprimidos, desde os pobres!" Era 1959, antes de muitas outras experiências (DUSSEL, 1998, p. 17).

Estava, assim, definido o foco/motivo de seu pensar: o pobre oprimido latino-americano. No retorno à Europa, passa pela Grécia, aquela que havia estudado como berço da filosofia e que, com a vivência do Oriente, se tornara estranha. Conclui, então, que "para a reconstrução de uma filosofia latino-americana era necessário 'destruir' o mito grego": "Atenas falava da dignidade dos nobres livres, da impossibilidade da emancipação dos escravos” (DUSSEL, 1998, p. 17).

Na França, Dussel faz os cursos de Paul Ricoeur na Sorbonne, momento em que descobre e se deslumbra com a fenomenologia de Merleau-Ponty e de Husserl. Ao mesmo tempo, se entusiasma com o personalismofenomenológico de Ricouer, especialmente com História e verdade (RICOUER, 1968), publicado originalmente em 1955 e que "ajudava o militante a compreender a história" (DUSSEL, 1995a, p. 9). A via longa, ou longo desvio, proposta pelo autor francês, relaciona uma hermenêutica dos símbolos com uma filosofia da reflexão concreta, levando Dussel (1995a, p. 9) a revisar sua tese de doutorado em termos de uma hermenêutica dos símbolos e escrever El humanismo helénico, em 1961, e El humanismo semita, concluído em 1964.

Na mesma Sorbonne, inicia um doutorado em História que resulta na tese El episcopado latinoamericano, institución misionera en defensa del indio (1504-1620): "era, o que havíamos descoberto, em Nazaré, o começo de uma história escrita desde os pobres, desde o índio americano" (DUSSEL, 1998, p. 19). Em 1965 escreve um pequeno livro sobre a história da igreja latino-americana e publica um artigo programático Iberoamérica na história universal. Em 1966, Dussel ministra um curso na Universidade de Resistência (Argentina), para o qual escreve um material intitulado Hipótesis para el estúdio de Latinoamérica en la história universal.

O retorno definitivo à Argentina ocorre em 1967. Como professor na Universidade Nacional de Cuyo, escreve, em 1968, El dualismo en la atropología de la cristianidad, fechando a trilogia sobre a hermenêutica antropológico-ética dos gregos, semitas e cristãos. Nesse trabalho aparece o tema do choque entre os mundos europeu e ameríndio: o enfrentamento assimétrico "com a conseguinte dominação de um sobre o outro; com a destruição do mundo ameríndio pela conquista em nome da Modernidade". Essas reflexões colocam em crise o modelo ricoeuriano, "apto para a hermenêutica de uma cultura, mas não para o enfrentamento

\footnotetext{
${ }^{3}$ Operário e socialista francês que havia conhecido na primeira viagem.
} 
assimétrico entre várias culturas (uma dominante e as outras dominadas)" (DUSSEL, 1998, p. 19). Essa preocupação se expressa nos seminários sobre a história da filosofia e resulta no texto Para una de-strucción de la historia de la ética ${ }^{4}$.

Naquele momento, era travado um importante debate a partir do livro de Salazar Bondy (1969). Nele, o autor pergunta se a filosofia latino-americana existe; em caso de resposta negativa, questiona a possibilidade e condições para sua criação; finalmente, discute até que ponto faria sentido e teria validade tomar como tema ou objetivo de atenção filosófica a realidade latino-americana. Em resposta, Zea (1969) afirma que existe uma tradição de pensamento autenticamente latino-americana que não pode ser ignorada e que a filosofia deve contribuir para a superação do subdesenvolvimento e da dependência, que não se trata de considerar o pensar latino-americano como um tema ou objeto específico, mas como um componente iniludível.

É preciso dizer que esses debates aconteciam no bojo de um contexto marcado por um conjunto importante de processos revolucionários e libertadores (com destaque para a Revolução Chinesa, para a Cubana e para os conflitos na América Central) e pela emergência e disseminação, na América Latina, da teoria da dependência (SANTOS, 2000), da teologia da libertação (GUTIERREZ, 1973), da pedagogia do oprimido (FREIRE, 1994) e da literatura latino-americana ${ }^{5}$ (RAMA, 1982). Dussel (1995a, p. 17-18) faz o seguinte relato pessoal desse contexto de origem de sua FL:

Desde que retornei à América Latina, chegando da Europa, a situação política ia de mal a pior. Os alunos exigiam dos professores mais clareza política. Na Argentina, a ditadura de Onganía recebia oposição cada vez maior dos grupos populares. Em 1969, rebenta o "Cordobazo" (a cidade de Córdoba é ocupada por estudantes e operários, reproduzindo-se o que acontecera no ano anterior no México, em Paris e em Frankfurt). A "teoria da dependência" abria caminho, apontando a assimetria econômica Centro-Periferia existente entre o desenvolvimento do Norte como causa do subdesenvolvimento do Sul. Na Colômbia, Fals Borda publica Sociología de la liberación; Augusto Salazar Bondy apresenta seu estudo ¿Existe uma filosofia em América Latina?, no qual faz depender da situação estrutural de neocolônias dominadas a impossibilidade de uma filosofia autêntica. Estávamos ministrando um curso de Ética ontológica dentro da linha heideggeriana na Universidade Nacional de Cuyo (Mendoza, Argentina) quando, em um grupo de filósofos, descobrimos a obra de Emmanuel Lévinas, Tótalité et Infinit: Essai sur l'Exteriorité. A minha ética ontológica passou a ser, então, Para una ética de la liberación latinoamericana $[\ldots]$.

O encontro com Lévinas (1997; 2000) permitiu a definição da posição de exterioridade indispensável para compreender a experiência da dominação e da exclusão porque fala sobre a outra pessoa, tratada como Outro (Autrui) e como pobre (Pauper). Dussel (1998, p. 20) explica porque essa "exterioridade metafísica do Outro" é fundamental:

Porque a experiência originária da FL consiste em descobrir o "fato" massivo da dominação, do constituir-se de uma subjetividade como "senhor" de outra subjetividade, no

\footnotetext{
${ }^{4}$ O registro extensivo destes primeiros textos ajuda a compreender a emergência da temática que será desenvolvida ao longo de toda sua trajetória pessoal e intelectual.

Rama (1982) identifica um boom literário na América Latina cujo início coincide com a publicação de Rayuela de Cortazár, em 1963 , tem seu ápice em 1967 com a publicação de Cien Años de Soledad, de García Márquez, e o declínio a partir de 1973, tendo como evento marcador o assassinato de Allende e a queda da democracia no Chile. Rama (1982) não caracteriza esse processo como um movimento, pois ninguém sabe exatamente o que é esse boom e tampouco quais autores fazem parte dele, pois não há uma lista definitiva. Esse boom pode ser chamado, talvez, de um acidente histórico que abarca autores ligados à narrativa literária presentes em listas de mais vendidos, ou seja, ligado à repercussão das obras e a certo compartilhamento impreciso de valores estéticos e culturais nas obras.
} 
plano mundial (desde o começo da expansão europeia em 1492 - fato constitutivo originário da "Modernidade") Centro-Periferia; no plano nacional (elites-massas, burguesia nacional - classe operária e povo); no plano erótico (homem - mulher); no plano pedagógico (cultura imperial elitista versus cultura periférica popular etc.); no plano religioso (o fetichismo em todos os níveis); no nível racial (a discriminação das raças nãobrancas) etc. [...] O pobre, o dominado, o índio massacrado, o negro escravo, o asiático da guerra do ópio, o judeu nos campos de concentração, a mulher objeto sexual, a criança sob a manipulação ideológica [...] não podem partir simplesmente da "estima de si mesmo" [...]. A anterioridade do Outro que interpela constitui a possibilidade do "mundo" ou de si mesmo como reflexivamente valiosa [...].

A anterioridade do Outro que interpela torna-se o fundamento do ato ético. Esse encontro, em conjunto com as formulações dependitistas sobre Centro e Periferia, permitiu, também, uma revisão da abordagem culturalista anterior a 1969 (influenciada por Heidegger e Ricouer). Segundo Dussel (2012a, p. 32), ocorre uma "ruptura com a concepção substancialista de cultura", com a cegueira perante a assimetria dos envolvidos e a descoberta de que os condicionamentos culturais "eram articulados (explícita ou implicitamente) desde a perspectiva de interesses de determinadas classes, grupos, gêneros, raças etc."

No entanto, apesar de ter superado a noção da totalidade hegeliana racional e da totalidade existencial heideggeriana, Lévinas $(1997 ; 2000)$ permanece concebendo um Outro abstrato ou passivo porque tem uma pedagógica, mas não uma política: "ele nos mostrava de que maneira apresentar a questão da 'irrupção do outro', mas nós não podíamos construir uma política (erótica, pedagógica etc.) que, questionando a Totalidade vigente (que dominava e excluía o Outro), pudesse construir uma nova Totalidade" (DUSSEL, 1995a, p. 22). Esse era, precisamente, o problema crítico-prático da libertação para o qual a contribuição de Lévinas era insuficiente.

Ocorre, naquela mesma época, o contato com os autores da primeira fase da Escola de Frankfurt (principalmente de Herbert Marcuse e Walter Benjamin ${ }^{6}$ ), considerada por Dussel (2002, p. 330) como "um movimento crítico que funciona como antecedente direto da FL e que se desenvolve no seio da crise da Modernidade tardia do capitalismo central". Essa influência se expressa: na reflexão sobre as condições de possibilidade da crítica negativa e teórica; na estratégia argumentativa que define o sistema vigente como uma Totalidade que se torna irracional e do qual é preciso emancipar-se; na definição da razão crítica como uma razão que considera a negatividade no nível material e prático; em um pensamento que se articula com as vítimas; na referência a comunidades com consciência explícita de sua condição de dominação; na concepção crítica da história valorizando os momentos libertadores do passado em relação às lutas do presente e os momentos nos quais a tomada de consciência das vítimas irrompe o descontínuo da história repetitiva (DUSSEL, 2002).

Dussel (1998, p. 21) se coloca, então, a "questão teórico-prática de uma nova Totalidade" - a questão da libertação para a qual se fazia necessário construir novas categorias e uma nova arquitetônica filosófica. A primeira destas categorias que precisa ser desenvolvida é a da "Totalidade no mundo do oprimido", dada a insuficiência de pensar ontologicamente o "ser da Totalidade vigente", de uma Totalidade que "justifica a opressão do oprimido e a exclusão do Outro". É preciso, portanto, romper com "a totalidade europeia do século XV ao século XX que colocou a outros homens como se fossem coisas em seu mundo" e esse mundo como se fosse "único, natural, incondicionado e exclusivo ponto de apoio de todo o pensar possível" (DUSSEL, 1995b, p. 231). A superação dessa ontologia implica em uma metafísica, em um ir além do horizonte do mundo (em grego, "mais além" e "mais alto" se diz aná, e palavra é logos). É preciso, desde a interpelação do Outro, afirmá-lo como outro e, assim, negar a negação dialética através de um "método analético", através da "afirmação original" do Outro (DUSSEL, 1998, p. 21).

${ }^{6}$ Ver Marcuse $(1967 ; 1969 ; 1977 ; 2004)$ e Benjamin (2006). 
Ana-lógos significa "palavra que irrompe no mundo mais além do mundo"; mais além do fundamento (DUSSEL, 1995b, p. 233). O método ontológico-dialético precisa ser superado porque chega apenas até o fundamento do mundo, detendo-se frente ao Outro da história distinta (não diferente - identidade e diferença são entes da totalidade, distinto é aquilo que é sempre e originalmente outro). A palavra do Outro é analógica porque irrompe interpelando, porque vem de mais além do meu mundo. Sendo assim, só é interpretável analeticamente porque "meu fundamento não é razão suficiente para explicar um conteúdo que escapa à minha história porque é a história do Outro" (DUSSEL, 1995b, p. 234). O método analético se diferencia do dialético porque o Outro como oprimido é o ponto de partida, porque "leva em conta a palavra do Outro como outro" e "implementa dialeticamente todas as mediações necessárias para responder a essa palavra" (DUSSEL, 1995b, p. 236). Ou seja, a analética é uma ampliação da dialética, incorporando uma nova possibilidade de construção do conhecimento na relação com o Outro, com a alteridade do distinto, com a exterioridade do sistema (DUSSEL, 1974). O ponto de partida da analética é a interpelação do oprimido, da comunidade de vítimas. Isso é o que leva à ampliação da dialética, pois exige uma experiência de 'nós' com os oprimidos, com a exterioridade do sistema vigente. A analética tem um momento afirmativo, em que se afirma a vida do oprimido, da comunidade de vítimas como um 'não-ser' que é resultado da exploração e da dominação. Nesse momento, há uma apreensão crítica da realidade, na qual o povo toma uma posição epistêmica. Apesar disso, a analética não se reduz à conscientização do oprimido (FREIRE, 1994), pois há um segundo momento, que é o de negação da negação da vida em concreto. Nesse momento, há a destruição dos sistemas de opressão e exclusão na prática. Nele, a experiência de 'nós' com os oprimidos não significa 'pensar pelo Outro' e muito menos 'fazer pelo Outro'. A analética exige 'estar junto com o Outro', com os oprimidos, na sua luta contra a opressão e contra a negação de sua vida pela Totalidade do sistema. A solidariedade com o Outro e a experiência de 'nós' com a comunidade de vítimas são o que permite o terceiro momento da analética, a realização superior da história, o novo em que os excluídos e oprimidos criam uma comunidade da qual são integralmente parte e em que constroem novas instituições ${ }^{7}$.

No que diz respeito aos pesquisadores que são interpelados pela comunidade de vítimas, a analética requer a abertura para pensar, para ouvir, para ver, para sentir, para provar o mundo desde a perspectiva do Outro. Ela é condicionada pela humildade, por uma solidariedade expectante. Ela permite o reconhecimento de que há uma política da Totalidade e uma política do Outro. "A política da Totalidade é dividida entre o senhor e seus oprimidos como oprimidos nesse sistema particular"; o oprimido é o Outro dessa Totalidade. Portanto, a "política do Outro é uma antipolítica, é uma política de subversão e contestação". É uma política que desafia hierarquias estabelecidas e verdades legais. "A política do Outro, a antipolítica da alteridade, proclama a injustiça e a ilegitimidade do sistema" em nome de uma nova legalidade, de uma nova legitimidade (MENDIETA, 2001, p. 21). Ou seja, trata-se de uma anti-política em relação à política do sistema.

Alcoff (2011, p. 67) considera a analética como a "epistemologia da nova revolução", uma epistemologia descolonizada que "coloca no centro não apenas as condições objetivas do empobrecimento e da opressão global, mas a sistemática desautorização da perspectiva interpretativa dos oprimidos do sul global". A autora considera que a analética é o projeto de uma epistemologia política que parte do sentido da inadequação moral e política das abordagens dialéticas para a realidade do trabalho vivo e para as condições dos oprimidos e, ao mesmo tempo, afirma que "as teorias sociais existentes não se engajam significativamente com algumas das dificuldades mais críticas enfrentadas pelos pobres". Exige, então, "uma compreensão mais adequada e mais abrangente da verdade sobre a experiência daqueles cujas experiências são frequentemente ignoradas" (ALCOFF, 2011, p. 71).

Dussel (1977a) exercita a analética na elaboração de uma história situada do mundo periférico dentro da história mundial, tratando de quatro problemáticas: erótica - libertação da mulher na Periferia mundial (índia, mestiça, mulher do povo, pobre); pedagógica - em diálogo com Paulo Freire (1994) e considerando a

\footnotetext{
${ }^{7}$ Para esclarecer a diferença entre a dialética negativa de Adorno (2009) e a analética, pode-se dizer, de modo sintético, que essa não é um movimento reflexivo que parte do pensamento puro, da identidade entre o conceito e a coisa, para a negação da compreensão do que é dado, para o concreto pensado. O caráter original da analética reside na experiência com o Outro.
} 
educação como um recurso histórico, comunitário, popular e anti-hegemônico para a educação de sujeitos individuais e sociopolíticos; política- referida ao contexto argentino e marcada pela experiência do poder popular e da esperança em uma revolução; antifetichismo - sobre a religião.

Em 1975, Dussel (1998) é levado ao exílio, tendo sido expulso da Universidade de Cuyo e condenado à morte pelos esquadrões paramilitares. Ao chegar ao México, escreve Filosofía de la Liberación (1977b), obra que define como correspondendo à sua etapa argentina.

Esse novo período é marcado por uma intensa aproximação com países da África e Ásia, bem como com muitas universidades norte-americanas e europeias, pela criação da Associação de Filosofia e Libertação (AFYL), pela aproximação com Cuba e Nicarágua - revoluções que apoia "por todos os meios", "em especial pela crítica filosófica do marxismo dogmático desde uma releitura firme e diferente do 'próprio' Marx” (DUSSEL, 1998, p. 24).

Esse "retorno sistemático a Marx" propicia a passagem da pragmática hermenêutica para a econômica. Esse retorno se deve, segundo Dussel (2102b, p. 20), a três fatos: (1) a crescente miséria do continente latinoamericano; (2) o desejo de levar a termo uma crítica do capitalismo; e (3) a constatação de que a FL precisaria construir uma fundamentação econômica e política firme. Realiza, então, uma interpretação hermenêutico-filosófica e cronológica de obras de Marx e conclui pela necessidade de inverter as hipóteses das leituras tradicionais, afirmando que o Marx dos últimos anos, das quatro redações de $O$ Capital (18571882), é o Marx mais antropológico e ético, é o Marx que produz "uma ontologia do capital através da metafísica da vida, da sensibilidade humana como necessidade, da pessoa do trabalhador como exterioridade".

No comentário sobre os Grundrisse, encontra-se uma leitura latino-americanamente situada de Marx com ecos de Lévinas: "A pobreza atroz, dilacerante, do nosso continente nos levou, há anos, a colocar a questão do "pobre" como categoria antropológica e metafísica - com origem e estatuto ético. [...] Os Grundrisse nos deram a pista para poder, agora, começar a construir, como estritas categorias analíticas, os conceitos de "pobre" e de "povo" - um, no singular, e outro no coletivo" (DUSSEL, 2012b, p. 19).

Dussel (2001) formula, a partir de suas leituras de Marx (2011; 2013a; 2013b) e Gramsci (1991), a concepção de que o povo não é um conglomerado amorfo (a massa). Além disso, o povo não deve ser confundido com classe, pois ela desaparece com a totalidade que a determina (o sistema econômico que se funda na exploração do trabalho). A categoria povo - referência sócio-histórica comunitária dos pobres subsume a de classe (nesse argumento entendida como classe operária, como trabalho vivo) também porque no mundo do capital ocorre a situação na qual o trabalhador é um nada:

O intercâmbio entre o capital e o trabalho parte de dois termos contraditórios: o capital, que possui trabalho objetivado como dinheiro, e o trabalho que, empobrecido, tem apenas que vender-se a si mesmo. Mas antes mesmo do intercâmbio, quando o trabalhador ainda não trabalhou para o capital, em sua exterioridade original, é um "trabalho ainda não objetivado". Enquanto "não" objetivado, é nada; negatividade para o capital; "são fantasmas que ficam fora do seu reino". [...] Por hora estamos nos referindo somente ao primeiro "nada" (seu "pleno nada"), o não-ser que permanece ainda fora do intercâmbio. [...] Cabe dizer, no "mundo" do capital o trabalhador não é nenhum ente: nada. Mais além do capital [...] é a não objetividade (porquanto ainda não é objeto; ou, se é objeto, enquanto não objetivado, é não objeto: um trabalhador desempregado). Se a riqueza é o capital, o que está fora é a "pobreza absoluta". Nada de sentido, nada de realidade, improdutivo, inexistente, não valor. Chamamos "o Outro" a esta posição da pessoa. Mas deve-se levar em conta que o trabalhador, enquanto homem, pode sempre tornar-se - mesmo quando um assalariado - "o Outro" da totalidade do capital. [...] Resumindo: como ente intramundano, como coisa ante a consciência, como mercadoria possível, mas atualmente não mercadoria, o trabalhador e seu trabalho são pura negatividade (DUSSEL, 2012b, p. 139-140). 
Essa exterioridade - o Outro do capital, o pobre - tem a potência de, no coletivo, como povo que tem um conteúdo material - "a corporalidade vulnerável que vive e pode morrer" -, se constituir em sujeito histórico, em bloco social dos oprimidos e explorados (DUSSEL, 2001, p. 218). Portanto, a importância política do conceito de povo é revolucionária. O povo é aquele que atravessa os diversos modos de apropriação de uma formação histórica "[...] com as memórias de suas gestas, com cultura própria, com continuidade no tempo. O povo é o coletivo histórico de pobre nos momentos limites da aniquilação de um sistema e de passagem a outro".

A existência desta vítima universal, da vítima do sistema como tal, exige sua libertação e, portanto, a dissolução total do sistema. A crítica das vítimas à ordem é "o juízo ético-crítico negativo por excelência" (DUSSEL, 2012a, p. 320), é o momento da positividade porque "toda negação da negação parte da afirmação da exterioridade":

O trabalho não objetivado, nada no mundo das mercadorias, afirma-se como subjetividade, como atividade quando se relaciona consigo mesma. $\mathrm{O}$ exterior, a alteridade do trabalho não objetivado, o outro do capital [...] se afirma a si mesmo como fonte viva do valor [...]. A "fonte" é o manancial mais além do fundamento (o valor do capital) da totalidade como tal. Mais além (metá, em grego) do ser (fýsis, em grego) está o metafísico, o transontológico, a exterioridade do capital: o trabalho como atividade da subjetividade humano-viva, corporalidade, rosto e mãos sensíveis. É por isso que, quando vender o seu trabalho, o trabalhador "exporá" [...] a sua própria corporalidade ao ser deglutido pelo capital. Mas antes do intercâmbio, o trabalhador (à diferença do escravo ou do servo do feudalismo) se afirma como outro, como pessoa (DUSSEL, 2012b, p. 139-140).

Ou seja, o conceito de trabalho vivo não pode ser separado da pessoa e de sua existência corporalmente imediata: esse é o significado de materialidade nas formulações de Marx e da primeira fase da Escola de Frankfurt ${ }^{8}$. Trazendo-o para a América Latina, Dussel (2011a) afirma que a filosofia precisa, inevitavelmente, confrontar esta materialidade negativa e lidar com ela não apenas no nível econômico, mas considerando a esfera material inteira, ou seja, considerando suas origens econômicas e políticas, sua história e instituições sistêmicas. Essas várias dimensões se conjugam mutuamente, mas, seguindo Lévinas, há uma situação ética originária que ocorre no encontro com o Outro, encontro que se situa no momento anterior à fala: a primeira pergunta, portanto, é sobre a possibilidade do ser desde a sua inevitável relação com a alteridade do Outro.

O retorno a Marx (2013) também possibilita esclarecimentos sobre o tema da dependência. Dussel (1988) realiza uma extensa discussão das vertentes latino-americanas a partir da teoria marxista do valor e das elaborações de autores como Lenin (2007), Luxemburgo (1985) e Emmanuel (1972). Feita essa discussão, ele foca na Dialética da Dependência (MARINI, 2005) e no que considera um equívoco do autor dessa obra, apesar de valorizá-la como um trabalho excelente e como um dos poucos a tratar o tema a partir do marxismo. Segundo Dussel (1988, p. 312), Marini (1973) partiu do problema correto da transferência de valor dos países periféricos para os centrais. No entanto, tomou um "mecanismo secundário, derivado e fundado na essência da transferência" - a superexploração do trabalho - como a essência da dependência. Para Dussel (1988, p. 348), a dependência, "na lógica do pensamento do próprio Marx, é um conceito irrefutável": "a dependência existe no nível essencial ou fundamental, abstrato, e consiste na relação internacional entre burguesias possuidoras de capitais globais nacionais de diversos graus de desenvolvimento". No marco da competição, o "capital global nacional menos desenvolvido se encontra 'socialmente' dominado (relação entre pessoas) e, em última análise, 'transfere mais-valia (momento formal

${ }^{8}$ Os autores vinculados ao que se chama de primeira fase da Escola de Frankfurt são, entre outros, Adorno, Benjamin, Bloch, Fromm, Horkheimer, Marcus e Pollock. Para uma visão geral dos principais autores vinculados à Teoria Crítica e suas obras, recomendamos a leitura de Bronner (1997). 
essencial) ao capital mais desenvolvido, que o realiza como lucro extraordinário". A partir dessa posição, tira conclusões políticas sobre a libertação nacional e popular, desenvolvendo o conceito de "segunda emancipação": "libertação da dependência [...] e libertação, na nação, do povo oprimido". Neste trabalho que dedica "ao povo nicaraguense que, por sua revolução sandinista ${ }^{9}$, está elaborando na práxis uma nova versão do marxismo" (DUSSEL, 1988, p. 11), conclui, referindo-se à autodefinição dessa luta como um "movimento de libertação nacional e popular":

Nacional: na superação da dependência capitalista o país poderá acumular como riqueza própria o fruto do trabalho de seus trabalhadores. Popular: não apenas as classes oprimidas pelo capitalismo passado, mas todos aqueles que eram 'nada' para o capital global nacional nicaraguense (desempregados, etnias, marginais etc.) a partir de sua 'cultura' (e de sua religião como parte de sua cultura popular) como afirmação do 'trabalho vivo', concreto, histórico, poderão organizar um novo modo de vida liberado. (DUSSEL, 1988, p. 361)

Essa transcrição é interessante porque evidencia o compromisso do autor com as lutas de seu tempo. Em uma versão deste mesmo capítulo publicada posteriormente, Dussel (1990, p. 95-6) conclui com uma declaração política mais genérica sobre o contexto da região: "no nível da economia política [o conceito de dependência] é o ponto de partida do conceito de libertação. É o momento teórico a partir do qual e a partir de onde se origina e começa o processo de libertação em nosso continente". Como um balanço desta "releitura hermenêutico-filosófica e cronológica categorial (reconstrutiva) da obra de Marx", Dussel (1998, p. 25) recoloca o conceito de dependência para descrever a causa da diferença Norte-Sul e reafirma a exterioridade do pobre.

Na segunda metade da década de 1980, reconhecendo a importância do giro linguístico, inicia um diálogo crítico com a ética do discurso ${ }^{10}$. A partir de 1989, Dussel e Karl-Otto Apel se envolvem, ao longo de dez anos, em um debate Norte-Sul (APEL e DUSSEL, 2004). No debate com Dussel, a Ética do Discurso de Apel (2004, p. 60) tem como ponto de partida a ideia de que a comunidade comunicativa real é "uma forma de vida sociocultural a que qualquer destinatário da ética há de pertencer sempre, devido a sua identidade contingente, a seu nascimento e socialização". No contexto dessa comunidade, Apel propõe uma ética universalista do dever ideal que está tomada pelo princípio a priori da intersubjetividade. Reconhecendo que o ser humano não é puramente racional, mas que não pode ser separado da realidade e da história, Apel propõe uma divisão da Ética do Discurso em A e B, de modo que a parte A da Ética do Discurso oferece "a fundamentação de um princípio formal de procedimento, uma meta-norma, da fundamentação discursiva" de novas normas universais suscetíveis de consenso. A parte B, por sua vez, expressa "como a exigência de uma fundamentação consensual pode vincular-se às relações situacionais, no sentido de uma ética de responsabilidade histórica". A Ética do Discurso estipula a "obrigação de colaborar com a eliminação a largo prazo, aproximativa, dessa diferença" entre as partes A e B. Isso só pode acontecer em uma comunidade comunicativa em que as condições ideais de uma possível formação de consenso sobre normas faz a formação concreta da sociedade depender de acordos passíveis de falhas e correções por todos os envolvidos (APEL, 2004, p. 65). Assim, a arquitetônica da Ética do Discurso alia aspectos formais, orientados pela universalidade do dever, a aspectos procedimentais, vinculados aos acordos e normas que são consensualizados em concreto.

${ }^{9}$ Ver, a esse respeito, Zimmermann (2006) e Fagundes (2009).

${ }^{10}$ A Ética do Discurso continua a tradição da filosofia europeia na discussão da moral universal integrando as duas correntes da llustração pelas quais passou a filosofia europeia, ou seja, o racionalismo e o empirismo. Karl-Otto Apel e Jürgen Habermas são as duas principais referências sobre o tema. A opção neste texto foi, por motivos de espaço e de relevância para as formulações da arquitetônica da ética da libertação, explorar as resultantes de seu diálogo crítico com Apel. Sobre a crítica às proposições de Habermas, ver o capítulo 2 de Dussel (2002). 
Explicitando sua situação, Dussel (2004b, p. 75) discute o mito da Modernidade e sua relação com a falácia desenvolvimentista ${ }^{11}$, ou seja, "tentar realizar, por extrapolação, no capitalismo dependente e explorado o que pensa e realiza o capitalismo central desenvolvido". A Modernidade nasceu com a abertura da Europa para o mundo quando, em outubro de 1892, "descobre" o "novo" continente; nasce, então, a América Latina como a outra cara da Modernidade, sua cara necessária, explorada, dominada - a contrapartida dialética da Modernidade (DUSSEL, 1994). Assim, "a experiência de estar 'fora' da Europa, de ser a parte explorada do mundo capitalista", impõe, "filosoficamente", a necessidade da "libertação do explorado, do oprimido, do dependente" (DUSSEL, 2004b, p. 79). É preciso, também, libertar a filosofia dos aparelhos institucionalizados que reproduzem o pensar eurocêntrico.

A partir do fato da exclusão, Dussel (1998, p. 25) se posiciona neste debate considerando, inicialmente e "desde uma comunidade de comunicação empírica e hegemônica" (uma comunidade de comunicação real, não ideal), a impossibilidade de "não excluir o Outro". A própria afirmação da exterioridade do Outro, ao irromper na Totalidade, abre a possibilidade de negar a negação: desde o não-ser é criada a possibilidade de uma comunidade de vida. A interpelação do pobre, do Outro, é, portanto, um momento anterior à ação comunicativa. A interpelação é um "enunciado performativo sui generis emitido por alguém que se encontra, com relação a um ouvinte, 'fora' ou 'além' do horizonte ou marco institucional normativo do sistema" (DUSSEL, 2004a, p. 149). Mas essa exclusão não é apenas das comunidades de comunicação, ela também é uma exclusão da comunidade de reprodução da vida. Portanto, não se trata de uma questão formal, mas material.

Em defesa da articulação do formal com o material, Dussel (2004c) leva em consideração o principus exclusionis: o Outro, o afetado na Exterioridade, o excluído da comunidade de participação que não pode participar (mesmo se for representado) coloca a questão moral do problema da validade da comunidade de comunicação. A diferença fundamental entre a ética do discurso e a ética da libertação é que a primeira parte da comunidade de comunicação e a segunda parte dos excluídos dessa comunidade. Portanto, há um nó crítico na aplicação da norma básica de moralidade procedimental da ética do discurso porque a materialidade empírica histórica é relegada a uma posição secundária e irrelevante. Ela não tem relevância porque a validade, definida pela ética do discurso como uma universalidade racional de consenso formal intersubjetivo, tem prioridade com relação ao conteúdo ético (DUSSEL, 1977a). Já para a ética da libertação, "o princípio concreto liberta hic et nunc ${ }^{12}$ o oprimido transforma o afetado-excluído em um participante" e tem uma lógica procedimental diferente: as situações de exceção para a prática da ética do discurso são situações usuais para a ética da libertação (DUSSEL, 2004c, p.275).

Esse debate (1) propiciou uma aproximação positiva com aspectos formais e procedimentais; (2) esclareceu as razões pelas quais o discurso ético tem dificuldades com os fundamentos e aplicação de normas morais. Ao longo do debate, Dussel (2002) foi redigindo sua Ética da libertação, uma "arquitetônica" que objetiva "incorporar os aspectos materiais do bem e a dimensão formal da validade e do consenso ético" (DUSSEL, 1997, p. 1). Essa arquitetônica inclui um conjunto de princípios e critérios: vida humana como conteúdo material da ética; moralidade formal a partir da validade intersubjetiva; factibilidade ética - o bem; crítica ética a partir da negatividade das vítimas do sistema; validade intersubjetiva da comunidade das vítimas; libertação. Nos próximos parágrafos, será feito um esforço de apresentação dessa arquitetônica, em que são destacadas a formulação do princípio material ético-normativo da ética da libertação, sua factibilidade e a práxis da libertação.

\footnotetext{
${ }^{11}$ A oposição de Dussel ao desenvolvimentismo não está vinculada especificamente a uma ou outra corrente sobre o tema. A sua reflexão sobre o tema extrapola os limites do historicismo e da discussão economicista e oferece um aporte filosófico que afirma que "a falácia desenvolvimentista consistiria em cair no 'mal infinito' de Hegel (por mais que o escravo trabalhe nunca chegará a ser 'senhor livre'; ao contrário, enriqueceria ao 'senhor' e seria mais escravizado: os países periféricos, como o escravo, devem primeiro libertar-se da relação de dominação, para depois desenvolver-se autonomamente" (DUSSEL, 2004b, p. 75).

12 Liberta aqui e agora
} 
A tese de Dussel (2004d, p. 344) é que "o aspecto do 'conteúdo' da ética, abstratamente (a reprodução e desenvolvimento da vida do sujeito humano em comunidade), tem universalidade própria e determina sempre materialmente todos os níveis da moral formal13". Ou seja, para Dussel (1997, p. 6), "a moralidade formal sempre pressupõe uma ética material14 que determina o critério da verdade universal e concreto".

Se a vida humana é o critério de verdade prática, o princípio material é assim enunciado: "todo aquele que atue eticamente deve produzir, reproduzir e desenvolver a vida humana em comunidade e, em última análise, a vida de toda a humanidade, isto é, com pretensão de verdade prática universal" (DUSSEL, 2001, p. 74). Esse critério (da reprodução e desenvolvimento da vida humana em comunidade), sendo interno a cada cultura, permite a autocrítica em relação aos seus momentos intrínsecos que impedem essa vida e, a partir de sua universalidade, permite um diálogo com outras culturas. No entanto, o princípio material não é suficiente para decidir conflitos, contradições, confrontações externas com outras concepções da vida ética. Por isso, é preciso um princípio moral universal intersubjetivamente válido que subsuma as realizações da ética do discurso invertendo seu sentido - não se trata de uma forma básica que se deve aplicar ao empírico-histórico, mas de uma norma básica formal que tem a função de aplicar o princípio material: "a norma material é a condição de possibilidade do 'conteúdo' da 'aplicação' da norma formal porque se há argumentação é porque se tenta saber como se pode (deve) reproduzir e desenvolver a vida [...]; a norma material dá o 'conteúdo' do consenso [...] em um horizonte marcado pela impossibilidade de escolher morrer" (DUSSEL, 2004d, p. 350).

Segue-se, nesta arquitetônica, a dimensão da factibilidade ética: "trata-se de escolher as mediações adequadas ou eficazes para determinados fins. [...] Quem não cumpre estas exigências empírico-tecnológicas tenta um ato impossível" (DUSSEL, 2004d, p. 253). O princípio material ético-normativo da libertação articula elementos de ética material e de moral formal, de modo que para garantir a factibilidade da práxis da libertação é preciso cumprir não apenas com um enunciado formal, mas estabelecer os meios adequados que possibilitam a práxis. Ou seja, sendo a práxis da libertação uma ação que almeja transformar a realidade subjetiva e social a partir da referência última de alguma vítima ou comunidade de vítimas, "a possibilidade de efetivamente libertar as vítimas" é um critério que se coloca em um nível concreto, complexo e real (DUSSEL, 2002, p. 558). Por isso, é necessária a organização e sua efetivação através de processo e práticas orientados por uma razão estratégico-crítica que se oriente pelo pleno desenvolvimento da vida de todos. Essa organização libertadora decorre da conscientização: como indica Freire (1994), uma consciência aprofundada da situação opressora leva as pessoas a apreenderem essa situação como uma realidade histórica suscetível de transformação, o que demanda uma intervenção crítica e, portanto, organização. Defendendo a presença da razão estratégico-crítica na arquitetônica da ética da libertação, Dussel (2004d, p. 353) afirma que "não se pode cair em fetichismos e descartar a função própria e subalterna da razão instrumental". O princípio da factibilidade ética é enunciado nos seguintes termos:

É concreta e eticamente operacionável ou factível uma ação, norma institucional ou sistêmica, que cumpra (a) com as condições de possibilidade lógica, empírica, técnica, econômica etc., isto é, que em todos esses níveis sejam possíveis, o que é julgado desde as (b) exigências (deônticas): (b.1) ético-materiais da verdade prática, e (b.2) morais-formais da validade; dentro de um espectro que vai desde (b.a) ações permitidas eticamente (que são as meramente "possíveis" já que não contradizem os princípios éticos ou morais), até (b.b) ações devidas (que são "necessárias" para o cumprimento das exigências humanas básicas: materiais - de reprodução e desenvolvimento da vida do sujeito humano; formais de participação dos afetados nas decisões) (DUSSEL, 2004d, p. 353).

\footnotetext{
${ }^{13}$ A moral formal estabelece critérios válidos intersubjetivamente, com pretensão de universalidade.

14 (ica material fica delimitada pelo critério de verdade prática da ética. Na proposta de Dussel (2002, p. 169), a verdade prática do conteúdo da ação (dimensão material) deve articular-se adequadamente com a validade intersubjetiva (moral formal), "[...] constituindo, a partir da factibilidade concreta, uma unidade complexa em que cada aspecto determina o outro de maneira diferente e constitui aquilo que se pode chamar de a norma, a ação, a práxis, as estruturas do sujeito eticamente 'bom"'.
} 
Trata-se, portanto, da práxis da libertação, definida como "a ação ou processo prático pelo qual o não-livre passa a ser um sujeito fático da liberdade, o oprimido como "parte funcional' se afirma como pessoa sujeito" (DUSSEL, 2004c, p. 269). Na práxis da libertação estão os três últimos momentos sucessivos da arquitetônica: (1) a crítica ética a partir da negatividade das vítimas se constitui na fonte positiva da negação e do projeto de libertação - "o descobrir-se en-cobertos, ignorados, afetados-negados, leva ao início da tomada de consciência do si mesmo positivo, mas dialeticamente codeterminada pela consciência da relação negativa com o sistema", situação indispensável para "um projeto ético-estratégico histórico" que antecipa a "nova" comunidade "na qual os não-participantes sejam participantes" (DUSSEL, 2004c, p. 285); (2) a negação da negação e a práxis de-construtiva da libertação que constrói a validade intersubjetiva antihegemônica da comunidade das vítimas - esse processo se refere a cada possível sistema concreto de dominação (capitalismo, liberalismo, racismo, destruição ecológica etc.) porque existem muitas frentes de luta e muitos sujeitos da práxis, sendo "necessário descobrir em cada 'frente' um processo concreto, teórico, prático, ético"; (3) a libertação - passagem ao novo sistema, práxis construtiva da liberdade (DUSSEL, 2004c, p. 287).

A possibilidade de "efetivamente libertar todas as vítimas é o critério sobre o qual se funda o princípio mais complexo desta ética": o princípio libertação, que subsume todos os demais em um nível mais complexo, real e crítico (DUSSEL, 2002, p. 558). Esse princípio "enuncia o dever-ser que obriga eticamente a realizar a transformação, exigência que é cumprida pela própria comunidade das vítimas, sob sua responsabilidade, e que se origina prático-materialmente, como normatividade a partir da existência de certo poder ou capacidade (o ser) na dita vítima" (DUSSEL, 2002, p. 559). A referência, aqui, é à confrontação entre lutas sociais organizadas pelas vítimas e o sistema formal dominante. O princípio libertação é enunciado da seguinte maneira:

Aquele que opera ético-criticamente deve (está obrigado a) libertar a vítima, como participante (por "situação" ou por "posição" - diria Gramsci) da própria comunidade a que pertence a vítima, por meio de (a) uma transformação factível dos momentos que causam a negatividade material (impedem algum aspecto da reprodução da vida) ou discursivoformal (alguma simetria ou exclusão da participação) da vítima; e (b) a construção, através de mediações com factibilidade estratégico-instrumental críticas, de novas normas, ações, microestruturas, instituições ou até sistemas completos de eticidade onde essas vítimas possam viver, sendo participantes iguais e plenos. [...] deve-se levar em conta que a realização prática positiva, ou a práxis da libertação propriamente dita, tem sempre por sujeito sócio-histórico próprio de referência a própria comunidade crítica das vítimas - seja qual for o rosto com que se revele - e está sempre a cargo da responsabilidade da própria comunidade das vítimas: é um ato de autolibertação de um sujeito histórico específico (DUSSEL, 2002, p. 265).

Ou seja, as vítimas, a partir do exercício de uma razão crítica universal, constituem uma nova comunidade de comunicação anti-hegemônica, com validade crítica e, como atores históricos, lutam pelo reconhecimento de suas demandas. São "atores que emergem como construtores de uma nova universalidade (a partir da diferença) e por meio de uma práxis libertadora" (DUSSEL, 1998, p. 31).

A Ética da libertação representa, para Dussel (2002), o encerramento de um processo de reflexão que havia se iniciado em 1969. Durante esse processo, ele valoriza, cada vez mais, as dimensões da filosofia política e econômica, encaminhando-se para novos projetos.

Aproxima-se, então, da hipótese de Gunder Frank (1998) segundo a qual o centro da economia está novamente se movendo para o Oriente, mais especificamente para a China, e que esse movimento não é novo: no passado, o centro do mundo se localizava na Ásia até a ascensão, em termos econômicos e demográficos, da dominação Ocidental (em torno de 1800). Nas palavras de Dussel (2012a, p. 41), "fomos, então, capazes, de introduzir uma nova proposição teórica - que chamamos de 'trans-moderna' - e que constitui uma superação explícita do conceito de pós-modernidade". A nova proposição parte do 
reconhecimento de que a Europa moderna começa a funcionar como centro do mercado mundial apenas com o advento da revolução industrial e, no nível cultural, com sua decorrência - o Iluminismo. Sendo assim, a hegemonia europeia durou apenas dois séculos, um período pequeno para as transformações profundas que concretizou em culturas tradicionais (como, p. ex., a da China e outras do Extremo Oriente, a dos povos Bantos da África subsaariana, a dos povos originários da América Latina). Essas culturas foram parcialmente colonizadas, ou seja, a maior parte de seus valores tem sido excluída, mas não aniquilada. "Essa exterioridade negada, essa alteridade - sempre existente e latente - indica a realidade de uma riqueza cultural insuspeita que é lentamente revivida", tendo claro que ela não está miticamente preservada, ela vem se transformando face à própria Modernidade, mas preserva uma identidade que é sempre a de uma exterioridade. Portanto, elas são "simultaneamente pré-modernas (mais antigas que a modernidade), contemporâneas à Modernidade e, brevemente, também trans-modernas". Assim, o conceito de "transmoderno tenta indicar a radical novidade da irrupção - como que emergindo do Nada - de uma exterioridade transformativa que é sempre Distinta, de culturas universais em processo de crescimento e que assumem o desafio da Modernidade, e mesmo da pós-modernidade europeia/norte-americana, mas que respondem desde outro lugar, de outra localização" (DUSSEL, 2012a, p. 42). Face à essa constatação, Dussel (2012a, p. 43) defende a possibilidade de um futuro "de rica pluriversidade", uma "nova era da história mundial" que assuma os momentos positivos da Modernidade, que resulte de "diálogos interculturais autênticos" (tendo sempre em mente as assimetrias existentes), que se situe além das estruturas valorizadas pela moderna cultura europeia/norte-americana, e no qual seja valorizada a presença de "núcleos criativos das culturas ancestrais que são decisivamente distintos de todos os outros e que têm a capacidade de propor respostas novas e necessárias para os desafios angustiantes que o planeta enfrenta".

Seguindo nessa direção, Dussel (2007a, p. 11-2) dedica-se, então, à construção de uma "possível história da política" dos povos e do pensamento ou filosofia política que rompe com os seguintes limites: (1) o helenocentrismo - a história sempre inicia na Grécia e desconsidera o mundo egípcio e mesopotâmico, fenício, semita, da Idade do Bronze, do III e II milênios A.C.; (2) o ocidentalismo que leva a desprezar a importância do Império Romano oriental, de Bizâncio ou Constantinopla; (3) o eurocentrismo das filosofias políticas que esquecem, "por desprezo e ignorância", tudo o que foi alcançado por outras culturas, tais como as já mencionadas egípcias e mesopotâmicas, mas também as do Império Chinês, do Indostão e do Islã, bem como as da América Latina (dos reinos astecas, maias e incas, p. ex.); (4) a periodização que segue os critérios ideológicos eurocêntricos de organizar o tempo da história humana, p. ex., em Idade Antiga, Medieval e Moderna; (5) o secularismo ${ }^{15}$ tradicional e inadequado da política; (6) o colonialismo teórico e mental das filosofias políticas dos países periféricos que leem e interpretam, em geral, as obras da Modernidade política europeia desde seu território, mas dentro da problemática dos filósofos do centro, sem se dar conta da visão metropolitana desta hermenêutica e sem realizar uma leitura crítica e situada da metrópole colonial; (7) não incluir a América Latina na Modernidade desde sua origem, já que ela foi participante principal da política moderna. Esse contrarrelato foi realizado como um buscar do não dito, como "um dizer" que tem como ponto de partida "a corporalidade sofredora de nossos povos", "desde a dor das oprimidas e dos oprimidos, das excluídas e dos excluídos, das condenadas e dos 'condenados da Terra'16 e da história" (DUSSEL, 2007a, p. 13).

No segundo volume dedicado à Política da libertação, Dussel (2009, p. 11) trata do momento ontológico e normativo da política, definida como "a práxis realizada em um campo específico estruturado por instituições". Afastando-se do contratualismo e do liberalismo ${ }^{17}$, o autor define a categoria central em torno

\footnotetext{
${ }^{15} \mathrm{O}$ secularismo tradicional ao qual o autor se refere é aquele que ignora que na história da política as relações entre o poder instituído e as religiões sempre foram muito presentes.

${ }^{16}$ Referência à obra de Franz Fanon (1968).

${ }^{17}$ O liberalismo parte de uma suposição de igualdade em uma situação originária a partir da qual as instituições políticas são criadas. Essas instituições se desprendem dos sujeitos da situação original e ganham autonomia. Ao estipular a diferenciação ontológica entre potentia e potestas, Dussel permite identificar o poder obedencial nas relações entre o povo e o poder institucionalizado, localizando no primeiro a potência do poder. Essa diferença ontológica é fundamental para compreender a criação de novas instâncias por parte do povo nas quais o poder institucionalizado é negado devido à sua fetichização em relação à potentia.
} 
da qual organiza sua política da libertação: o poder político que divide, pela diferença ontológica originária, em (a) potentia - o poder político em si na comunidade política ou povo; e (b) potestas ${ }^{18}$ - o exercício delegado do poder político institucionalizado. A potentia (poder originário, indeterminado) da comunidade política (origem e local da regeneração da potestas) é o fundamento da política. No entanto, enquanto tal, se não for determinada de alguma maneira heterogeneamente institucionalizada permanece vazia, como um nada político: pura potência sem realização.

Nas palavras de Dussel (2009, p. 60): “a potentia é o poder da própria comunidade política; é (a) a pluralidade de todas as vontades (momento material) ou da maioria hegemônica, (b) juntamente com o consenso (momento formal discursivo), que (c) conta com meios instrumentais para exercer seu poder e colocar mediações (momento das mediações, da factibilidade)" (DUSSEL, 2009, p. 60). A necessidade das mediações, sem as quais o poder-em-si seria pura potência, existência ainda não realizada, leva a uma "clivagem ontológica" originária: a potentia, o poder político da comunidade se constitui como vontade política consensual instituinte, se dá instituições para que o poder desde abaixo (a potentia) possa ser exercido: é o poder obedencial. A força do poder desde abaixo "é potência, é positiva, não é dominação, não é opressão, não é determinação negativa, mas afirmação da vida da comunidade para viver" (DUSSEL, 2009, p. 61). No entanto, "quando a potestas se fetichiza, isto é, se corta, se separa de seu fundamento (a potentia), diminui seu poder, ainda que seu exercício despótico pareça alcançar o paroxismo da força (como no caso de A. Hitler ou A. Pinochet)". Quando ocorre essa separação, "o poder institucional e delegado faz sua aparição fenomênica como poder ôntico" - é o poder mandando, o poder autorreferido (DUSSEL, 2009, p. 61). A Figura 1 pode ajudar a compreender essa arquitetônica:

Figura 1

Da potentia à potestas

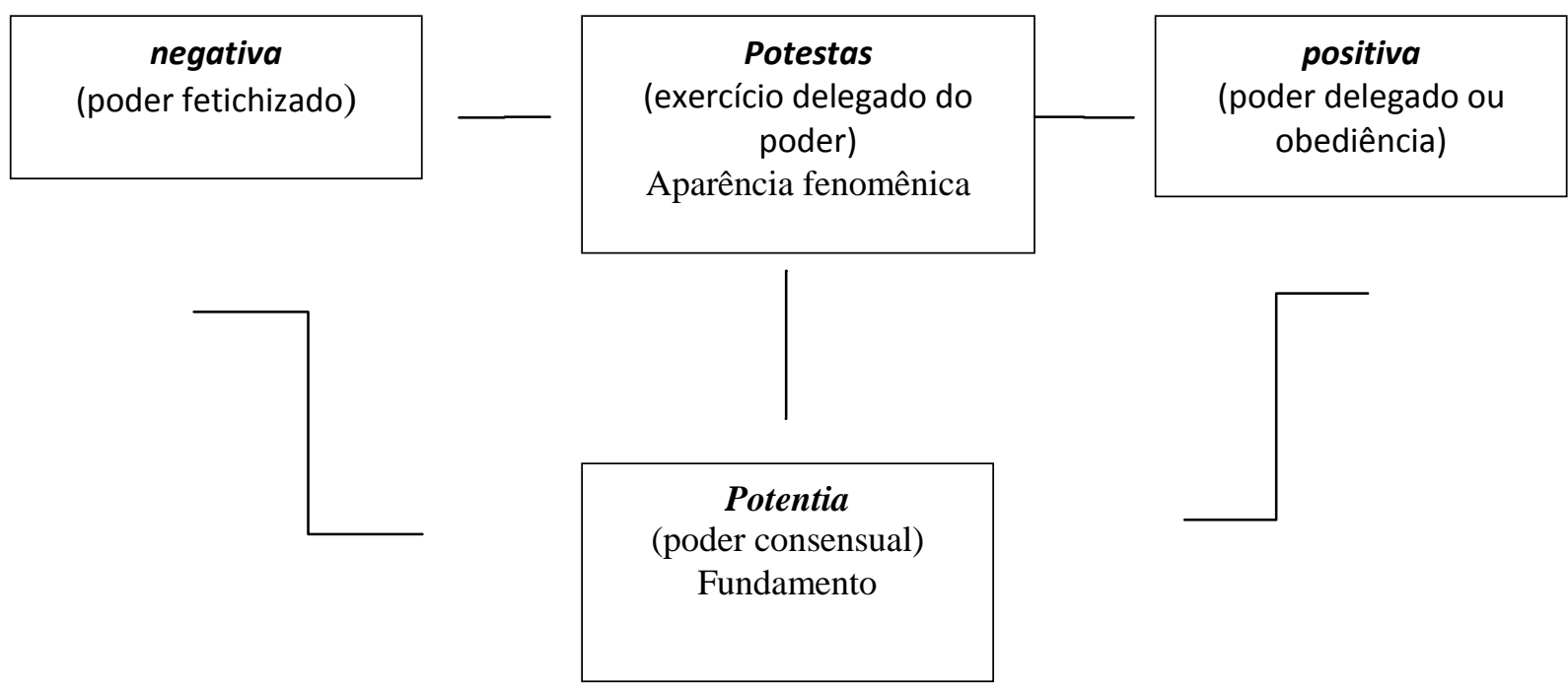

Fonte: adaptado de Dussel (2009, p. 62).

Dussel (2009, p. 470) retoma o tema da razão estratégica a serviço da libertação. O autor parte da distinção realizada por Aristóteles entre logos poietickós (razão instrumental) de logos praktikós (razão prática, no seu caso, estratégica) e faz as seguintes considerações: "a primeira determina a relação sujeito-natureza como razão técnica; a segunda determina a relação sujeito-sujeito como razão estratégica. A razão estratégicopolítica assume a complexidade dentro da qual se inscreve toda ação ou instituição para ser realizada". O autor não segue as proposições de Weber (1997) por considerar que sua concepção de racionalidade

\footnotetext{
${ }^{18}$ Dussel denomina o poder político institucionalizado de potestas, seguindo as proposições de Spinoza (2008).
} 
instrumental é reducionista: nela, os fins já estão dados pelo sistema vigente, sem que haja a possibilidade nem de propor fins nem de julgá-los. Na política, o problema normativo da razão estratégica consiste, precisamente, em avaliar a compatibilidade dos fins da ação com a possibilidade de reprodução da vida humana - a verdade do fim - e com a procedimentalidade democrática - a legitimidade do fim.

Para esclarecer sua posição, Dussel (2009, p. 473-4) opõe os argumentos dos críticos progressistas, dos conservadores e dos anarquistas radicais. Para os conservadores, a ordem vigente representa o melhor mundo possível e a crítica é uma impossibilidade; trata-se da "fetichização do passado-presente". Para os críticos progressistas, o impossível dos conservadores pode ser possível. Para os anarquistas radicais, o que é impossível tanto para o conservador como para o crítico progressista, é uma ordem intolerável e superada; "tendo um horizonte de possibilidades quase ilimitado, porque se propõe fins empiricamente impossíveis, perde o sentido estratégico e entra em um campo ilusório onde ações não razoáveis (para não dizer irracionais) se tornam factíveis". Dussel (2004d; 2009) dirige ressalvas como essa diretamente às proposições de Holloway (2003) sobre mudar

o mundo sem tomar o poder. Na mesma direção, critica Hardt e Negri $(2004 ; 2011)$ por suporem que a forma Estado é uma instituição da modernidade burguesa que precisa ser superada para iniciar algo que pudesse ser adequadamente chamado de política. Para Dussel $(2009 ; 2012 c)$, esses autores ignoram que esse Estado é uma forma particular, não a única; esquecem que as atuais comunidades de povos originários, que tomam como modelo de democracia direta, tiveram organização estatal (como os incas) que não era nem burguesa, nem liberal; não compreendem que o novo Estado (para além do Estado moderno e burguês) que aceleraria a dissolução do Estado deve ser inventado desde baixo, mas não pode se restringir a organizações comunitárias de base pouco numerosa.

Contra esse conjunto de autores, Dussel (2004d) defende que a organização, mais além das impossibilidades conservadora e anarquista extrema, é criadora e pode transformar inventivamente as estruturas vigentes evitando o espontaneísmo (participação sem organização) - "uma política sem continuidade que não pode afetar realmente a história". Ainda que propicie lembranças de grandes momentos, "cuja vivência nos enche de esperança", o "espontaneísmo não tem boa memória, nem arquivos, nem história; ele aconselha a irrupção intempestiva e a criatividade sem qualquer disciplina" - trata-se de uma fetichização da participação (DUSSEL, 2001b, p. 19).

Em outra direção, para Dussel (2007b), o bloco histórico dos oprimidos, a partir da articulação das demandas heterogêneas e diversas dos setores subalternos, deve construir a mudança da ordem político-institucional de modo a garantir as condições para a produção, reprodução e desenvolvimento da vida humana em comunidade. Retomando os princípios da ética da libertação, Dussel (2002) defende que o bloco subalterno e oprimido irrompe na história quando toma consciência de sua situação e constrói intersubjetivamente um estado de rebelião que impugna a ordem social e as instituições que a administram. Essa ação se orienta por três princípios: (a) o princípio político da libertação que critica a esfera material - momento da negatividade expressa na negação da vida das vítimas que abre espaço para o processo instituinte de outra ordem; (b) o princípio crítico democrático de transformação estratégica; (c) a práxis da libertação dos movimentos sociais. O processo político orientado por esses princípios pode construir uma nova hegemonia e transformar as instituições políticas na esfera material, na esfera da legitimidade democrática a partir da alteridade do Outro e não da ideia de igualdade liberal, e na esfera da factibilidade a partir da delegação obedencial do poder e da dissolução do Estado burguês.

Apresentaremos, para encerrar essa parte, a posição de Dussel (2008) com relação à abordagem do póscolonialismo $^{19}$. Dussel $(2008$, p. 340) reconhece a emergência simultânea, em torno de 1970, dos trabalhos

\footnotetext{
19 "Pós-colonialismo, como tem sido usado em vários campos, descreve um conjunto marcadamente heterogêneo de posições, campos profissionais e empreendimentos críticos. Ele tem sido usado como um meio para ordenar uma crítica às formas totalizadoras do historicismo Ocidental, como um termo guarda-chuva para uma noção refeita de 'classe', como um subconjunto do pós-modernismo e do pós-estruturalismo [...]; como o nome para uma condição de pertencimento nativo em grupos nacionais pós-independência; com um marcador cultural de não-residência para um quadro intelectual do terceiro mundo; como um inevitável outro lado do discurso fraturado e ambivalente do poder colonialista; [...] como o nome de uma categoria de atividade literária [...]" (SLEMON, 1994, p. 51).
} 
de Guha, na Índia, com os da FL, na América Latina, bem como o fato de que ambos os processos ocorreram sob a influência da filosofia francesa, resultando na existência de traços comuns. Para chegar a essa conclusão, ele revisa a emergência do pensamento crítico na periferia pós-colonial a partir dos estudos da cultura popular de massa e dos grupos subalternos na Índia (GUHA, 1997), com o posterior enriquecimento pela participação, entre outros, de autores como Spivak (1988; 1990), Bhahba (1994) e Chakrabarty (1988; 2002), que, influenciados por Foucault e Lacan, se envolveram com temas como gênero, cultura, política e raça. No entanto, essas elaborações podem ser mal interpretadas e distorcidas se a situação originária não for levada em consideração. Além disso, a FL não deve ser considerada como se fosse apenas um modo de "pensamento latino-americano", mas como "uma filosofia crítica autocriticamente localizada na periferia, nos grupos subalternos". Além disso, ele defende a necessidade de narrativas históricas para a reconstrução de memórias e para a produção de sentido das lutas sociais, argumentando pela insuficiência de micronarrativas. Dussel (2008, p. 343) reconhece que os "dualismos simplistas de centro-periferia, desenvolvimento-subdesenvolvimento, dependência-libertação, explorador-explorado, todos os níveis da bipolaridade dominador-dominado a respeito de gênero, classe e raça, civilização-barbárie, princípios universais-incerteza, e totalidade-exterioridade, devem ser superados se forem usados de uma maneira superficial ou redutiva". No entanto, "superar não pode implicar em decretar sua inexistência ou inutilidade epistêmica", sob o risco de "cair em um pensamento perigosamente utópico ou reacionário". Em vez disso, "essas categorias dialéticas duais devem ser colocadas em níveis concretos de maior complexidade" que, "sem o fetichismo ou o terrorismo linguístico que, sem qualquer validação, caracterizam como 'antiquadas' ou 'obsoletas' posições que são expressas em uma linguagem que o falante não gosta". Ele está se referindo expressamente à rejeição às temáticas marxistas da luta de classes e do proletariado feita por alguns autores vinculados à perspectiva pós-colonial. Diz Dussel (2008, p. 343):

A luta de classes nunca vai ser superada, mas não é a única luta; é uma entre muitas outras (aquelas das mulheres, ambientalistas, minorias étnicas, nações dependentes etc.) e em certas conjunturas outras lutas podem se tornar mais urgentes e de maior significado político. Se o "proletariado" não é um "sujeito metafísico" para toda a eternidade, isso não significa que não exista mais um sujeito coletivo ou intersubjetivo, um que pode aparecer e desaparecer em certos períodos históricos. Esquecer sua existência seria um grave erro.

A posição de Dussel (2008) não é de recusa ao diálogo com as abordagens pós-coloniais, mas de reconstruir algumas de suas contribuições de acordo com as demandas políticas de grupos subalternos. Essa posição é muito importante, reiterando que a FL é uma filosofia em ação, uma filosofia a serviço das lutas sociais, do bloco dos oprimidos. Isso não significa, de modo algum, que cabe ao intelectual falar pelo Outro:

O filósofo da libertação não representa ninguém, ele não fala pelos outros [...] nem se encarrega de uma tarefa concreta de modo a superar ou negar algum tipo de sentimento pequeno burguês de culpa. O filósofo crítico latino-americano, como concebido pela Filosofia da Liberação, assume a responsabilidade de lutar pelo outro, pela vítima, pela mulher oprimida pelo patriarcado, pela geração futura que vai herdar uma Terra devastada etc. - isto é, assume a responsabilidade por todos os tipos de alteridade. E o faz com uma consciência ética "situada", com a consciência de qualquer ser humano com "sensibilidade" ética e com capacidade de indignar-se quando reconhece a injustiça imposta ao outro (DUSSEL, 2008, p. 342).

Qual é, então, o significado da FL para nós, acadêmicos? Como podemos nos engajar no desenvolvimento de uma eticidade crítica-libertadora? Como já deve ter ficado claro, é sempre a vítima quem tem uma consciência ética original, histórica e concreta. Portanto, ensina Dussel (2004c, p. 356) que é preciso "saber escutar a interpelação do Outro em sua corporalidade sofredora". Apenas em um segundo momento pode ocorrer a crítica temática científica ou filosófica. Além disso, esse momento apenas é possível "para aqueles que têm alguma 'experiência' do 'nós' com os dominados e/ou excluídos" e podem, portanto, "pensar reflexivamente a in-felicidade do Outro". Para realizar a crítica temática, é preciso que nos situemos 
negativamente com relação ao "sistema ou mundo da eticidade vigente, ao bem válido (capitalismo, machismo, racismo etc.), desde a alteridade das vítimas, dos dominados e/ou excluídos, em posição crítica e desconstrutiva da 'validade hegemônica' do sistema", ou seja, julgando-o como ilegítimo. O princípio éticocrítico é enunciado da seguinte maneira por Dussel (2004c, p. 359):

Quem atua ético-criticamente sempre reconhece in actu as vítimas de um sistema (sistema de eticidade, norma etc.) dado que lhes negou a possibilidade de viver (em sua totalidade ou em alguns de seus momentos), pelo que está obrigado a, em primeiro lugar, 1) negar a "bondade" de tal sistema, isto é, criticar primeiramente a não-verdade do sistema que agora aparece como dominador e, em segundo lugar, 2) atuar criativa e co-solidariamente para transformá-lo.

\section{Filosofia da Libertação, Estudos Organizacionais e possibilidades de uma crítica ética e radical}

Podemos, agora, refletir sobre as contribuições de Dussel e de sua FL para a crítica nos EOs em diálogo com algumas apropriações que vêm sendo realizadas nesta área, com destaque para o contexto brasileiro.

Desde já, é preciso reiterar que a apropriação coerente das formulações desta FL deve respeitar os princípios ético-críticos e, portanto, precisa contribuir para a deslegitimação da totalidade do sistema vigente em articulação com os sujeitos históricos que colocam o corpo em suas lutas de libertação. Atingir esse nível de coerência em uma área de estudos que se encontra colonizada pelo management é, evidentemente, um desafio. Lembremos que o management é, como ensinava Tragtenberg (1980, p. 3) referindo-se às formulações daquele que é reconhecido como o criador do management contemporâneo (BYRNE, 2005; IBARRA-COLADO, 2006; MALIK, 2009; OSTDICK, 2013) - Peter Drucker ${ }^{20}$ - "uma ideologia neocapitalista" que tem a "função de legitimar o status quo como único possível e desejável". Nessa mesma direção, Parker (2002, p. 222) esclarece que o management está vinculado a um projeto de profissão e a uma grande indústria de legitimação, apresentando-se como uma "tecnologia neutra de organizar". Sendo assim, diz ele, "não é uma questão de quem gerencia", de substituir a boa gestão pela má gestão, mas de construir formas alternativas de organizar. A partir desse raciocínio, Misoczky, Flores e Goulart (2014) defendem que também não se trata de substituir o conhecimento sobre management produzido no Norte pelo produzido no Sul, mas de se opor integralmente à essa tecnologia de opressão, exploração e negação da vida.

Retomando, podemos reconhecer o ano de 2006 como o momento em que algumas proposições de Enrique Dussel começam a circular através de canais institucionalizados nos EOs. Naquele ano, ocorreram três publicações que, apesar de expressarem posições diferentes, induziram uma apropriação marcadamente culturalista e recortada da FL. Nos próximos parágrafos, vamos nos engajar criticamente com esses artigos: o primeiro é a sistematização feita por Ibarra-Colado da apresentação de Dussel no Encontro do Asia Pacific Researchers in Organization Studies, realizado em Oaxaca (México); o segundo é um texto de Ibarra-Colado sobre colonialidade epistêmica nos EOs latino-americanos; o terceiro é um balanço realizado por Misoczky sobre o IV Encontro Nacional de Estudos Organizacionais.

Interpretamos o texto de Dussel e Ibarra-Colado ${ }^{21}$ (2006) como equivalente ao ocorrido no processo da tradução de Economia e sociedade (WEBER, 1997) para a língua inglesa, quando Talcott Parsons também traduziu as formulações weberianas para os marcos do seu estrutural-funcionalismo ${ }^{22}$. Ibarra-Colado faz algo

\footnotetext{
${ }^{20}$ Ver, por exemplo, Drucker (2002).

${ }^{21}$ Precisamos esclarecer que as críticas que aqui realizamos não implicam em desrespeito à trajetória exemplar de Eduardo IbarraColado e que muitas delas foram feitas pessoalmente a ele, em diversas oportunidades, sendo algumas delas em debates públicos.

${ }^{22}$ Ver, por exemplo, Cohen, Hazzelrigg e Pope (1975).
} 
semelhante, sistematizando a apresentação de Dussel em termos dúbios, em uma versão escrita por ele e que, curiosamente, foi revisada pelo próprio Dussel ${ }^{23}$.

Para iniciar, há, na nota elaborada por Ibarra-Colado, uma desconsideração do significado de 'organização' para Dussel. Vejamos: Dussel (2002) sempre trata o tema da organização subordinando-o ao princípio libertação: a organização é uma necessidade para viabilizar a práxis libertadora, é um meio para que as vítimas do sistema, a partir da tomada de consciência da sua situação e da construção intersubjetiva de um estado de rebelião, transformem as instituições políticas na esfera material e produzam uma nova hegemonia a partir de sua Alteridade. No entanto, na nota explicativa que se encontra em Dussel e Ibarra-Colado (2006, p. 506), encontramos o seguinte registro: "O termo 'organização', tão popular no mundo anglo-saxão, persiste como uma abstração cuja existência permitiu ao funcionalismo 'desumanizar' a relação entre indivíduos. Se não fosse assim, seria impossível compreender que formas de organização - e seus problemas - são consequências de relações de poder que afetam os níveis de desenvolvimento e bem-estar da humanidade". Temos aqui pelo menos dois problemas: o primeiro e mais evidente é que, em contradição com Dussel (2002) e sua recusa à ideia liberal de igualdade, encontramos exatamente a ideia liberal da relação humanizada entre indivíduos; a segunda é a prisão à definição de organização como ente estruturado que predomina nos EOs colonizados pelo management.

O texto que estamos analisando é muito interessante. Estamos convencidos de que todos aqueles que têm familiaridade com os escritos autorais de Dussel, com sua linguagem enfática e intencionalmente dramática (características que procuramos preservar no item anterior), ficaram surpresos ao ler este artigo e com a sensação de uma versão asséptica. Em nossa interpretação, a linguagem atenuada, certamente mais palatável aos leitores da administração e dos EOs, induz a uma apropriação que trai os princípios da FL em vários aspectos. Vamos considerar com mais detalhes dois desses aspectos: a ação ética e a organização, e a práxis .

No item sobre os três aspectos da ação ética, a tradução para a linguagem predominante nos EOs e para sua categoria central reificada - a organização do sistema produtivo - é totalmente desconectada do tratamento dado por Dussel ao tema da organização - expressão do princípio factibilidade e da razão estratégico-crítica para concretizar a libertação do bloco dos oprimidos, do povo e, portanto, para a dissolução do sistema opressor.

Na redação que se encontra em Dussel e Ibarra-Colado (2006, p. 501), encontramos o seguinte trecho com relação ao primeiro aspecto da ação ética: "Se, em vez de defender a vida humana, as formas de organização dão prioridade ao aumento e apropriação do lucro, então elas não vão prestar atenção para as necessidades materiais dos seres humanos. O resultado será a exclusão, a privação econômica e política, as deficiências culturais e libidinais. Elas vão também colocar em risco a sustentabilidade do planeta". O texto continua nesse mesmo tom, referindo-se aos "problemas da organização" e aos efeitos negativos ignorados sobre a vida humana. Há um tom ingênuo, como se a prioridade do lucro não fosse compulsória e o desprezo pelos impactos adversos sobre a vida e o planeta não fossem inerentes ao sistema. A conclusão sobre esse aspecto é, novamente, contraditória com as proposições de Dussel (2002) sobre o princípio material da ética (a reprodução e desenvolvimento da vida do sujeito humano em comunidade): "Portanto, em vez do lucro e do benefício pessoal, o imperativo básico material que deve guiar a ação humana organizada deveria ser a defesa da vida de cada indivíduo humano". Essa é uma afirmação que poderia ser aceita por muitos humanistas liberais com seu enfoque individualista e meramente atenuador de algumas consequências de uma ordem supostamente eterna.

\footnotetext{
${ }^{23}$ O texto em questão "foi escrito para a conferência inaugural de Enrique Dussel [...]. O segundo momento consistiu de uma transcrição da conferência feita por Eduardo Ibarra-Colado, que aceitou a tarefa de estruturar e reescrever a primeira versão, incluindo as notas que acompanham o texto. Para isso, foi necessário interpretar o sentido das palavras de Dussel, decifrando os sons e imagens em vídeo e revisando textos publicados pelo autor. O momento final foi, novamente, nas mãos de Dussel, que revisou e corrigiu a versão final [...]" (DUSSEL e IBARRA-COLADO, 1996, p. 505). Não cabe especular sobre as razões da concordância de Dussel com essa versão final, mas cabe sim, indicar as incoerências com as formulações do próprio Dussel e com as consequências desse texto para a decorrente apropriação desse autor nos EOs.
} 
Continuando, o segundo aspecto, segundo Dussel e Ibarra-Colado (2006, p. 502-3), é sobre "quem decide como devemos desenvolver a vida humana". Trata-se do princípio formal que, para Dussel (2004c, p. 275), se expressa no "liberta aqui e agora o oprimido, transforma o afetado em participante", um "princípio moral universal intersubjetivamente válido" que tem a "função de aplicar o princípio material" (reprodução e desenvolvimento da vida). Pois, na versão que estamos analisando, ele se transforma "na bem conhecida discussão sobre os princípios formais que permitem decisões e cooperação entre indivíduos". Agora, trata-se apenas de aspectos relativos à participação dos trabalhadores e do pessoal externo na organização: "Apenas alguns poucos devem tomar as decisões? Ou, aqueles que coletivamente produzem e reproduzem a organização com seu trabalho devem ter algo a dizer? Mais ainda, devem os indivíduos que não estão diretamente envolvidos, mas são afetados pelas decisões da organização ser autorizados a participar? Finalmente, há um procedimento formal pelo qual a organização pode ser construída como um esforço coletivo de um consenso moral?” É inevitável pensar em Barnard (1971) e suas proposições sobre a ligação intrínseca e transcendente entre cooperação e organização, destacando os aspectos de moralidade nelas contidos. Além disso, é muito interessante como o Outro do sistema desaparece. Agora, todos fazem parte do sistema e todos podem contribuir através da razão comunicativa para sua melhoria. Não há mais excluídos: "Precisa haver uma transição; da imposição do ego dominante sobre o Outro para uma construção intersubjetiva das razões de todos" (DUSSEL e IBARRA-COLADO, 2006, p. 503). É o retorno à ética do discurso e a desconsideração da ética da libertação ${ }^{24}$.

Nas passagens de Dussel e Ibarra-Colado (2006) citadas no parágrafo acima, o Outro que é vítima de um sistema de opressão (DUSSEL, 2002) desaparece. Ignorando que a exploração do trabalhador "estabelece um novo tipo de 'excluído' da comunidade de comunicação dos empresários, capitalistas, membros hegemônicos no 'mundo da vida' da sociedade colonizada pelo 'sistema' que eles controlam" (DUSSEL, 2004a, p. 161), os autores deixam de concebê-los como Exterioridade à Totalidade do sistema vigente e o concebe como mero indivíduo às margens da comunidade de comunicação. A impossibilidade ontológica da vítima participar da comunidade de comunicação, denunciada por Dussel (2004a; 2004b, 2004c, 2004d), transforma-se na urgência da uma construção intersubjetiva de todos. Desaparece, portanto, a razão do Outro expressa na interpelação da corporalidade sofredora que grita "Eis aqui uma vítima!", restando uma comunidade de comunicação ideal na qual trabalhadores, pessoal externo, empresários e membros hegemônicos poderiam chegar a um consenso moral.

Cabe destacar, ainda, que a formação do consenso moral corresponde a uma dimensão política, que também é deixada de lado pelos autores. Na formação deste consenso, Dussel e Ibarra-Colado (2006) atribuem um caráter comunitário a uma realidade que Dussel (2004c) chama de não-comunitária. Assim, os autores transitam da ética para um consenso moral que não considera as relações de opressão e exploração inerentes às organizações produtivas capitalistas e substituem a consciência da opressão das vítimas por uma moral organizacional que articularia e pacificaria os conflitos sociais.

O terceiro aspecto da ação ética é o da factibilidade, traduzido para "promoção da participação simétrica na construção de uma forma coletiva e racional de organização". O princípio da factibilidade em Dussel (2004c, p. 253), como vimos no item anterior, se refere a construir mediações que levarão a uma nova Totalidade para substituir a vigente - essa que justifica a opressão e a exclusão do Outro. Portanto, ela se refere à construção de viabilidade, à utilização da razão estratégico-crítica para criar mediações e "efetivamente libertar as vítimas". Porém, em Dussel e Ibarra-Colado (2006, p. 502), factibilidade passa a ser "agir de acordo com o que é possível sob condições reais"; em outras palavras: "a factibilidade determina a gestão [management no original] das ações sociais que permitem a vida e a participação". Ou seja, a construção factível de uma nova Totalidade, necessidade que decorre da conscientização intersubjetivamente

\footnotetext{
${ }^{24}$ É importante destacar que em lbarra-Colado (1999) há uma importante reflexão crítica sobre como as Teorias Organizacionais contribuem para transformar a organização em um ente moral cuja validade é naturalizada que, de certo modo, é contraditória com o este enfoque.
} 
compartilhada do bloco social dos oprimidos, é transformada em uma espécie de contigencialismo, de adaptação às circunstâncias do possível.

Concluindo este tema, Dussel e Ibarra-Colado (2006, p. 502) escrevem que "se a ação humana organizada levar em consideração esses três fatores [sic] éticos, a defesa da vida, o consenso e a factibilidade estarão garantidos. A reprodução de tal ordem social facilitaria sua difusão". Ou seja, nesta versão da ética que não é chamada de ética da libertação, mas de ação ética, o primado volta a ser o da ordem, do consenso e, até mesmo, da institucionalização.

A chamada "práxis transformativa", nesta versão, responderia a três princípios: (1) "reconhecer os limites materiais dos modos de organização que são dominantes e mostrar, do ponto de vista das vítimas, a necessidade de sua urgente transformação"; (2) a tomada de consciência pelas vítimas as "motivaria para construir novas formas de organização como alternativas concretas para uma vida melhor - isto é a libertação em sua forma mais pragmática"; (c) a libertação que "objetiva a implementação de futuros alternativos formalmente planejados" para que as instituições e suas formas de organização passem a funcionar "a serviço daqueles que têm sido excluídos" (DUSSEL e IBARRA-COLADO, 2006, p. 504). Não é preciso repetir as definições sistematizadas anteriormente para afirmar a tradução para a linguagem e prática da gestão. Não se trata mais de libertar-se de um sistema julgado inválido a partir da negatividade das vítimas pela práxis libertadora das próprias vítimas. Agora, há uma agente que mostra, pelas vítimas, a necessidade da transformação que, aliás, não é mais destruição do sistema, mas criação de novas formas organizacionais através de práticas formais de planejamento.

Outro problema com relação à apropriação da FL de Enrique Dussel pelos EOs decorre de uma abordagem cultural e essencialista da noção de transmodernidade e de sua crítica ao eurocentrismo.

Ibarra-Colado (2006) discute o estado dos EOs na América Latina em um esforço para revelar a colonialidade epistêmica que o define; Misoczky (2006) trata do fazer acadêmico e da possibilidade de enfrentar essa colonialidade ${ }^{25}$. Esses autores consideram que as categorias da alteridade e da exterioridade são importantes para compreender, respectivamente, a realidade organizacional na região e a subordinação dos EOs brasileiros. Lembremos que Dussel (2012) chega ao tema da transmodernidade como parte de uma trajetória de reflexões e proposições sobre a origem e vigência da dependência e de sua essência (a transferência de valor da periferia para o centro do sistema). Lembremos, também, que o Outro da Modernidade são as culturas tradicionais parcialmente colonizadas que permanecem vivas e latentes indicando, a partir de sua identidade negada e de sua exterioridade, alternativas à ordem vigente. Assim, o conceito de trans-moderno é proposto como um caminho para constatar a irrupção destas culturas distintas que, em sua práxis libertadora, confrontam o sistema.

O problema com os trabalhos de Ibarra-Colado (2006) e de Misoczky (2006) reside na suposição de que um fazer acadêmico institucionalizado e interior ao sistema, um fazer acadêmico em uma área de conhecimento que nasce no mercado e para servir ao mercado (a administração), possa ser tomado, pelo mero constatar da sua localização geopolítica e de sua evidente subordinação ao que é produzido nos países centrais, como o Outro do sistema. Vejamos como o tema é tratado na palavra dos autores:

Em síntese, o desenvolvimento dos estudos organizacionais na América Latina pode ser entendido como uma versão distorcida do funcionalismo ou do pensamento crítico do centro. [...] Para pertencer à 'comunidade internacional', você precisa falar a linguagem do

\footnotetext{
${ }^{25} \mathrm{Um}$ dos primeiros registros sobre o problema da colonialidade se encontra num artigo de Quijano (1993), publicado no contexto dos debates sobre os 500 anos da conquista europeia da América. Diz ele que colonialidade é um neologismo que tem, com relação ao termo colonialismo, a mesma ligação que modernidade em relação ao termo modernismo. A colonialidade do poder se refere ao prolongamento contemporâneo das bases coloniais que sustentaram a formação da ordem capitalista. Ainda que o colonialismo político tenha sido eliminado, a relação entre a cultura europeia (ou ocidental) e as outras continua sendo uma relação de dominação colonial (Quijano, 1992).
} 
centro, usar seus conceitos, debater suas agendas e se conformar com os estereótipos do 'sul imperfeito', enquanto mantém um 'silêncio educado' sobre as causas reais dos nossos problemas. (IBARRA-COLADO, 2006, p. 470-71)

Para descolonizar a pesquisa acadêmica é preciso focalizar em aspectos centrais, tais como os modos historicamente estabelecidos de produzir objetos de estudo, limites entre disciplinas, limites entre a academia e outros espaços sociais, práticas de pesquisa que produzem certos tipos de conhecimento, entre outros. É claro que a existência de atitudes colonizadas incide sobre uma maior ocorrência de reconhecimento e de incorporação não reflexiva das representações desenvolvidas no centro (MISOCZKY, 2006, p. 9).

Por mais bem intencionados que esses autores sejam, o fato é que transpõem inadequadamente o que para Dussel (2012a) e sua FL é um enfrentamento assimétrico articulado a partir de interesses específicos (de classe, gênero, raça, entre outros) e sobre o qual somos chamados, pela interpelação do Outro e sua corporalidade sofredora, a nos posicionarmos. Em vez disso, adotam uma concepção substancialista. Eles deixam de lado o conteúdo e dirigem suas críticas à postura academicamente subordinada de participantes do sistema acadêmico institucionalizado que ignoram as especificidades de sua localização geopolítica na produção do conhecimento sobre administração e management. Assim, a consideração ou não desse lócus de enunciação é tomado como critério de julgamento de sua validade. Nada mais afastado das proposições que revisamos no item anterior. Para ser coerente com elas, é preciso colocar no centro da crítica o conteúdo do conhecimento em administração e management (independentemente de sua localização espacial) e sua contribuição, através do desenvolvimento de tecnologias de gestão cada vez mais eficientes para a exploração do trabalho vivo e para o avanço destrutivo sobre a natureza, para a produção constante de vítimas e para a indispensável reprodução da opressão.

O caminho aberto por essa abordagem substancialista tem, por exemplo, uma expressão exacerbada nos trabalhos recentes de Faria e Wanderley (2013a; 2013b) voltados para "a descolonização 'estratégica' das organizações familiares" e para a "construção de uma área de estudos em estratégia no Brasil que reconheça a gestão estratégica da geopolítica do conhecimento e crie, assim, condições para a desmarginalização das

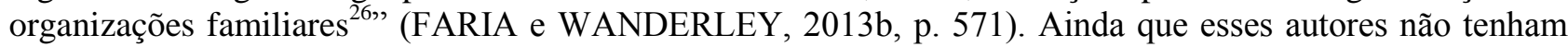
na FL sua principal referência, o fato de reivindicarem e se referirem a Enrique Dussel nos autoriza sua consideração no bojo deste ensaio.

Um primeiro estranhamento se deve ao uso repetitivo de termos da linguagem crítica sobre colonialidade como se fossem chavões e sem o devido tratamento teórico-conceitual. Um exemplo: "Fundamentalismo da gestão se confunde não apenas com fundamentalismo de mercado, mas também com fundamentalismo eurocêntrico (DUSSEL, 1993 ${ }^{27}$ ). Uma perspectiva 'outra', enunciada nos diversos cantos que compõem o resto do mundo, é necessária para a re-teorização e re-conceituação de organizações familiares e da gestão" (FARIA e WANDERLEY, 2013a, p. 2). O trecho induz um leitor não familiarizado com a obra de Dussel a supor que ele toma como tema de reflexão a gestão e a adequação de sua prática à América Latina quando, em sua obra, o tema da localização nessa região só tem sentido se articulado com o combate à dependência e à decorrente necessidade da exploração e opressão do Outro do capital: o trabalho vivo. Além disso, na transcrição acima, a palavra 'outra' é usada para meramente expressar uma localização espacial no 'resto do

\footnotetext{
${ }^{26}$ Não fica claro a que situação de marginalização os autores estão se referindo, já que, por exemplo, segundo a Revista Forbes de maio de 2013, 4 das maiores 10 empresas brasileiras apresentam constituição familiar em sua organização. Dentre elas estão o Banco Itaú e o Grupo Itaúsa, ambos controlados pelas famílias Setúbal e Villela e com valores de mercado de US $\$ 82$ bilhões e US\$ 25,4 bilhões respectivamente (ver:http://www.ciclosempresasfamiliares.com.br/2013/05/forbes-destaca-empresas-familiares-emranking-mundial/). Além disso, segundo dados de 2010 do IBGE, as empresas familiares responderam por $50 \%$ do Produto Interno Bruto (PIB) brasileiro, sendo que dos 300 maiores grupos empresariais no país, 265 são familiares (85\%).
}

${ }^{27}$ Essa referência se encontra em nossa lista como Dussel (1994) pelo uso de diferentes edições. 
mundo', o que justificaria a necessidade de aperfeiçoar a produção teórico-conceitual sobre organizações familiares e sobre gestão, isto é, aperfeiçoar um conhecimento a serviço da reprodução do sistema.

Outro exemplo da transposição inadequada de conceitos pode ser constatado no uso adaptado, a partir de Mignolo (2011), da expressão "un mundo donde quepan todos los mundos" que marca a luta do Exército Zapatista de Libertação Nacional (EZLN) pela criação, no México, de um Estado plurinacional que outorgue direitos e reconheça a diversidade dos povos originários ${ }^{28}$. Uma consigna que simboliza a contestação do sistema ilegítimo que produz vítimas e que, em contraposição, valoriza a vida, a organização e o conhecimento indígena ancestral, foi adaptada por Faria e Wanderley (2013b, p. 570) como um recurso discursivo para defender "a descolonização do campo da gestão pelo meio de teorizações que problematizem a gestão estratégica da geopolítica do conhecimento com base em perspectivas 'outras' que podem ajudar a construir um mundo no qual diferentes mundos (e conhecimentos) podem coexistir". Para esses autores, a pluriversidade descolonialista se justifica pela "ascensão do resto do mundo" no contexto das "seguidas crises da globalização neoliberal" e pela decorrente necessidade de uma "gestão estratégica no resto do mundo" (FARIA e WANDERLEY, 2013b, p. 570) e de "uma epistemologia da exterioridade" a partir de uma opção descolonial "sob uma perspectiva de transmodernidade pluriversal", citando Dussel, novamente. Vale recordar que esse autor se refere à possibilidade de um futuro pluriverso "que se situe além das estruturas valorizadas pela moderna cultura europeia/norte-americana" e valorize núcleos criativos das culturas ancestrais "distintos de todos os outros e que tenham a capacidade de propor respostas novas e necessárias para os desafios angustiantes que o planeta enfrenta" (DUSSEL, 2012a, p. 43). Ora, não há como negar que a gestão e as organizações empresariais (familiares ou não) pertencem, decisivamente, a essas estruturas criticadas e cuja validade é negada. Mais que isso, como fica implícito em um trecho entre parênteses no artigo de Faria e Wanderley (2013b, p. 571) - "não estamos argumentando que organizações familiares sejam intrinsecamente virtuosas" - sua epistemologia da exterioridade não leva em consideração o conteúdo e as consequências das práticas de gestão. Ou seja, traduzindo o Outro (vítima negada pelo sistema) por 'outra empresa' e 'outra gestão', Faria e Wanderley (2013a, 2013b) não problematizam a validade do sistema a partir da sua exterioridade material (a vida das vítimas que produz incessantemente).

Em outra direção, os participantes do Grupo de Pesquisa Organização e Práxis Libertadora, do qual os autores desse ensaio fazem parte ${ }^{29}$, têm tomado expressamente o referencial da FL não apenas em seu nome, mas na definição de "organização" que adotam em seus trabalhos: "a organização é um meio para realizar a ação libertadora através de processos e práticas territorializadas e orientadas pela razão estratégico-crítica" (MISOCZKY, 2010, p. 50). Um exemplo do trabalho que vêm realizando com base na FL pode ser encontrado em Misoczky e Böhm (2013a, p. 311). Nesse artigo, os autores abordam as lutas do povo de Andalgalá (uma pequena cidade na Província de Catamarca, Argentina) contra corporações mineiras transnacionais e seus aliados. Seguindo a tradição da FL e do método analético, se vinculam ao "que tem sido denominado 'comunidades argentinas do NÃO', expressando sua oposição a formas neocoloniais de desenvolvimento e gestão". Oferecendo "instantâneos de batalhas na linha de frente do extrativismo", os autores criticam, a partir da interpelação do bloco social dos oprimidos e dos seus impactos sobre a luta do

${ }^{28}$ Ceceña (2004) registra um trecho do discurso do Subcomandante Marcos no levante do EZLN em $1^{\circ}$ de janeiro de 1994: "Somos produto de 500 anos de luta [...], somos os herdeiros dos verdadeiros forjadores de nossa nacionalidade [...]". A autora explica que os zapatistas se referem à "sua longa marcha da escravidão à liberdade, identificando-se com os heróis que lutaram, durante anos, contra os poderes estrangeiros saqueadores da pátria e contra os governantes traidores e vendedores da pátria". Nesse texto, também se encontra o registro da frase que se tornou um dos importantes símbolos do EZLN e que foi proferida pelo Subcomandante Marcos em $1^{\circ}$ de janeiro de 1996, de acordo com Ceceña (2004): "O mundo que queremos é um onde caibam muitos mundos. A Pátria que construímos é uma onde caibam todos os povos e suas línguas, que todos os passos a caminhem, que todos a riam, que todos a amanheçam". Mais informações sobre o EZLN podem ser encontradas no link: http://enlacezapatista.ezln.org.mx/. Nele se encontra a recente declaração de organizações e coletivas de abaixo e à esquerda relativa aos 20 anos do levante armado dos zapatistas. Esse texto, bem como o acervo que se encontra neste sítio, não deixa dúvidas sobre o caráter político dessa organização de luta e resistência contra o sistema.

${ }^{29}$ Essa vinculação dos autores ao Grupo de Pesquisa foi introduzida na revisão final do texto, depois de encerrado o processo de avaliação que seguiu as normas do blind review. 
povo, "dois dispositivos gerencialistas usados pelas corporações mineiras, responsabilidade social corporativa e pactos de governança".

Em outro texto, esses mesmos autores se vinculam diretamente ao tema da ética da libertação. Misoczky e Böhm (2013b) engajam-se, desta vez, com o bloco dos oprimidos que luta, desde 2006 na Província de La Rioja (Argentina), para proteger sua forma de vida, bem como sua montanha e o glaciar de Famatina. Sob a consigna "El Famatina no se toca", as pessoas de uma região muito pobre - gente humilde, comum - têm sido capazes de expulsar poderosas corporações mineiras associadas aos governos nacionais e provincial, bem como com à mídia corporativa, agências financeiras internacionais e outras poderosas instituições: primeiro, Barrick Gold; depois, Shandong Gold e; mais recentemente, Osisko Mining Corporation. Os autores, além de se posicionar ao lado desses lutadores e difundir sua causa, analisam esse processo tendo como referência a transformação dessas pessoas comuns que, a partir da conscientização e da construção de um consenso crítico, se organizam em espaços horizontais autônomos e se constituem em um bloco social em constante estado de rebelião para impugnar a ordem social opressora e suas instituições. Essa metamorfose, de indivíduos isolados em povo que irrompe na história, é tratada nos termos da ética da libertação: quando os oprimidos percebem que sua vida se encontra ameaçada e despertam sua consciência crítica precisam se organizar utilizando a razão estratégico-crítica de modo a enfrentar um sistema nãoválido. Nesse processo, o bloco social dos oprimidos elabora novos projetos coletivos (política e organizacionalmente) com vistas a garantir a produção e reprodução da vida em comunidade e em harmonia com a natureza.

Encontramos outro exemplo, também no Grupo de Pesquisa Organização e Práxis Libertadora, nas análises críticas de Dornelas Camara (2012; 2013) sobre políticas compensatórias de distribuição de renda. Nessas análises, é feito um confronto da fundamentação moral dessas políticas (a partir de formulações do Banco Mundial e PNUD, de Amartya Sen e John Rawls, principalmente) com os princípios da ética da libertação, tendo como referência a pobreza (concreto-pensado) e o pobre (Exterioridade à Totalidade do sistema).

Esses trabalhos parecem se aproximar mais das potenciais contribuições da FL de Dussel em termos de uma renovação da crítica nos EOs. A consideração da obra desse autor, exemplo de intelectual orgânico (GRAMSCI, 1991) que, desde muito cedo, se definiu em uma posição de solidariedade ativa no encontro com as vítimas do sistema (o pobre, o oprimido, o Outro, o povo, o bloco dos oprimidos) nos coloca a questão sobre o significado de uma crítica ética e radical, ou seja, uma crítica que só pode ser definida a partir da realidade de exploração e opressão em cada formação histórica concreta e, em especial, nas formações do capitalismo dependente. Essa crítica nega a exploração do Outro, a moral capitalista, as variadas formas de opressão que o sistema necessita impor para reproduzir-se, bem como a decorrente destruição da natureza e do planeta. Essa crítica realiza essa negação a partir da positividade da vida daqueles que precisam viver. Ela oferece, portanto, um caminho para a superação da crítica domesticada que marca os Estudos Críticos em Administração desde sua origem (MISOCZKY e AMANTINO-DE-ANDRADE, 2005). No entanto, para que isso se efetive, será preciso revisar as apropriações parciais e, mesmo, deturpadas, das proposições de Dussel e de sua FL. Será preciso, além disso, colocar-se ativamente em solidariedade com as vítimas, respondendo à sua interpelação no destemor do agir ético pela dissolução do sistema e pela construção de uma nova Totalidade a partir do critério prático de verdade: a reprodução e desenvolvimento da vida humana em comunidade. 
Referências

ADORNO, T. Dialética Negativa. Rio de Janeiro: Jorge Zahar, 2009.

ADORNO, T.; HORKHEIMER, M. A dialética do esclarecimento. Rio de Janeiro: Zahar, 1985.

ALCOFF, L. An epistemology for the next revolution. Transmodernity: Journal of Peripheral Cultural Production of the Luso-Hispanic World, v. 1, n. 2, p. 67-78, 2011.

ALTAMIRANO, C. Ideias para um programa de história intelectual. Tempo Social, v. 19, n. 1, p. 9-17, 1997.

APEL, K.-O.; DUSSEL, E. Ética del discurso y ética de la liberación. Madri: Trotta, 2004.

BENJAMIN, W. Passagens. Belo Horizonte: UFMG, 2006.

BARNARD, C. As funções do executivo. São Paulo: Atlas, 1971.

BHABHA, H. The location of culture. London: Routledge, 1994.

BRONNER, S. Da teoria crítica e seus teóricos. São Paulo: Papirus, 1997.

BYRNE, J. A. The man who invented management, 2005. Disponível em: <http://www.businessweek.com/stories/2005-11-27/the-man-who-invented-management>. Acesso em 12 jun. 2013.

CECEÑA, E. El zapatismo: de la inclusión en la nación al mundo en el que quepan todos los mundos. 1/12/2004. Disponível em: <http://www.geopolitica.ws/article/el-zapatismo-de-la-inclusion-en-la-nacion-al-mundo/>. Acesso em: 13 jan. 2014.

CHAKRABARTY, D. Provincializing Europe: Post-Colonial thought and historical difference. Princeton: Princeton University Press, 2000.

CHAKRABARTY, D. Habitations of Modernity: essays in the wake of Subaltern Studies. Chicago: University of Chicago Press, 2002.

COHEN, J.; HAZZELRIGG, L. E.; POPE, W. Deparsonizing Weber: a critique of Parson's interpretation of Weber's sociology. American Sociological Review, v. 40, n. 2, p. 229-241, 1975.

DORNELAS CAMARA, G. Fundamentação moral do combate à pobreza no Brasil: um confronto entre os princípios orientadores do Banco Mundial, Rawls, Sen e do PNUD e o princípio ético-normativo da Filosofia da Libertação. Salvador, Anais do XII Colóquio Internacional sobre Poder Local, 2012.

DORNELAS CAMARA, G. Poverty eradication in Brazil: an analysis from the perspective of the Philosophy of Liberation. Manchester, Procedings of the $\mathbf{8}^{\text {th }}$. CMS Conference, 2013.

DUSSEL, E. Método para una filosofia de la liberación: superación analéctica de la dialéctica hegeliana. Salamanca: Sígueme, 1974.

DUSSEL, E. Para uma ética da libertação latino-americana. São Paulo: Loyola-UNIMEP, 1977a. v. I-V.

DUSSEL, E. Filosofía de la liberación. México, D.F.: Edicol, 1977b.

DUSSEL, E. Hacia um Marx desconocido: un comentario de los Manuscritos del 61-63. México, D. F.: Siglo XXI, 1988.

DUSSEL, E. Marx's economic manuscripts of 1861-63 and the "concept" of dependency. Latin American Perspectives, v. 17, n. 2, p. 62-101, 1990. 
DUSSEL, E. 1942 - El encubrimiento del Outro: hacia el origen del “mito de la Modernidad”. La Paz: Plural, 1994.

DUSSEL, E. Filosofia da libertação: crítica à ideologia da exclusão. São Paulo: Paulus, 1995a.

DUSSEL, E. Introducción a la filosofia de la liberación. Bogotá: Nueva América, 1995b.

DUSSEL, E. The architectonic of the Ethics of Liberation: on material ethics and formal moralities. Philosophy and Social Criticism, v. 23, n. 3, p. 1-35, 1997.

DUSSEL, E. En búsqueda del sentido (origen y desarrollo de una filosofía de la liberación. Anthropos, n. 180, p. 1336, 1998.

DUSSEL, E. Hacia una filosofía política crítica. Barcelona: Desclée de Brouwer, 2001.

DUSSEL, E. Ética da libertação: na idade da globalização e da exclusão. Petrópolis: Vozes, 2002.

DUSSEL, E. La razón del Otro: la "interpelación” como acto de habla. In: APEL, K.-O; DUSSEL, E. Ética del discurso y ética de la liberación. Madrid: Trotta, 2004a. 141-170 p.

DUSSEL, E. La introducción de la transformación de la filosofía de K.-O. y la Filosofía de la Liberación: reflexiones desde una perspectiva latinoamericana. In: APEL, K.-O; DUSSEL, E. Ética del discurso y ética de la liberación. Madrid: Trotta, 2004b. 73-125 p.

DUSSEL, E. Ética de la Liberación (Hacia el 'punto de partida' como ejercicio de la 'razón' ética originaria)'. In: APEL, K.-O; DUSSEL, E. Ética del discurso y ética de la liberación. Madrid: Trotta, 2004c. 269-290 p.

DUSSEL, E. Hacia una Arquitectónica de la Ética de la Liberación. In: Ética del discurso y ética de la liberación. Madrid: Trotta, 2004d. 339-366 p.

DUSSEL, E. Diálogo con John Holloway (Sobre la interpretación ética, el poder, las instituciones y la estrategia política). Herramienta, n. 26, Julho de 2004e. Disponível em: <http://www.herramienta.com.ar/revistaimpressa/revista-herramienta-n-26>. Acesso em: 24 jul. 2013.

DUSSEL, E. Política de la liberación: historia mundial y crítica. Madri: Trotta, 2007a.

DUSSEL, E. 20 teses de política. São Paulo: Expressão Popular, 2007b.

DUSSEL, E. Philosophy of Liberation, the Postmodern Debate, and Latin American Studies. In: MORAÑA, M.; DUSSEL, E; JÁUREGUI, A. (Eds.). Coloniality at large: Latin American and the Postcolonial Debate. Durham: Duke University Press, 2008. 335-349 p.

DUSSEL, E. Política de la liberación: arquitectónica. Madri: Trotta, 2009.

DUSSEL, E. From Critical Theory to the Philosophy of Liberation. Transmodernity: Journal of Peripheral Cultural Production of the Luso-Hispanic World, v. 1, n. 2, p. 26-43, $2011 \mathrm{a}$.

DUSSEL, E. Carta a los indignados. México, D. F.: La Jornada, 2011 b.

DUSSEL, E. Transmodernity and interculturality: an interpretation from the perspective of Philosophy of Liberation. Transmodernity: Journal of Peripheral Cultural Production of the Luso-Hispanic World, v. 1, n. 3, p. 28-59, 2012a.

DUSSEL, E. A produção teórica de Marx: um comentário aos Grundrisse. São Paulo: Expressão Popular, 2012 b.

DUSSEL, E. Estado o comunidad. Postado em 29/10/2012c. Disponível em: <http://marxismocritico.com/2012/10/29/estado-o-comunidad/>. Acesso em: 24 jul. 2013.

DUSSEL, E.; IBARRA-COLADO, E. Globalization, organization and the ethics of liberation. Organization, v. 13, n. 4, p. 489-508, 2006. 
DRUCKER, P. O melhor de Peter Drucker: a administração. São Paulo: Nobel, 2002.

EMMANUEL, A. El intercambio desigual. México, D. F.: Siglo XXI, 1972.

FAGUNDES, P. E. "Pátria o Muerte": os 30 anos da Revolução Sandinista. Revista Espaço Acadêmico, n. 103, p. 84$89,2009$.

FALS BORDA, O. Una sociología de la liberación. Bogotá: Siglo XXI, 1968.

FANON, F. Os condenados da terra. Rio de Janeiro: Civilização Brasileira, 1968.

FARIA, A. Fundamentalismo da gestão encontra a descolonialidade, repensando estrategicamente organizações familiares. Cadernos EBAPE.BR, v. 11, n. 1, p. 569-587, $2013 \mathrm{a}$.

FARIA, A.; WANDERLEY, S. Organizações familiares “otherwise”. III Colóquio Internacional de Epistemologia e Sociologia da Ciência da Administração, Florianópois, março de 2013 b.

FREIRE, P. Pedagogia do oprimido. Rio de Janeiro: Paz e Terra, 1994.

GADAMER, H.-G. Verdade e método: traços fundamentais de uma hermenêutica filosófica. Petrópolis: Vozes, 1997.

GRAMSCI, A. Selections from the Prison Notebooks. London: Lawrence and Wishart, 1991.

GUHA, E. (Ed.). A subaltern studies reader: 1986-1995. Minneapolis: University of Minnesota Press, 1997.

GUNDER FRANK, A. ReOrient: global economy in the Asian Age. Berkeley: University of California Press, 1998.

GUTIÉRREZ, G. A theology of liberation: history, politics and salvation. New York: Orbis Books, 1973.

HARDT, M.; NEGRI, T. Multitude: war and democracy in the age of empire. London: Penguin, 2004.

HARDT, M.; NEGRI, T. Commonwealth. Cambridge: Harvard University Press, 2011.

HOLlOWAY, F. Mudar o mundo sem tomar o poder. Campinas: Boitempo, 2003.

IBARRA-COLADO, E. Los saberes sobre la organización: etapas, enfoques y dilemas. In: CASTILLO MENDOZA (Coord.). Economía, organización y trabajo: un enfoque sociológico. Madri: Pirámide, 1999. 95-154 p.

MENDOZA (Coord.). Organization Studies and epistemic coloniality in Latin America: thinking otherness from the margins. Organization, v. 13, n. 4, p. 462-488, 2006.

IBGE. Instituto Brasileiro de Geografia e Estatística. Estatísticas do cadastro central de empresas. Brasília: IBGE, 2010 .

LENIN, V. I. O imperialismo, fase superior do capitalismo. Brasília: Nova Palavra, 2007.

LÉVINAS, E. Entre nós: ensaios sobre a alteridade. Petrópolis: Vozes, 1997.

LÉVINAS, E. Totalidade e infinito: ensaios sobre a exterioridade. Lisboa: Edições 70, 2000.

LUXEMBURGO, R. A acumulação do capital: contribuição ao estudo econômico do capitalismo. São Paulo: Nova Cultural, 1985.

MALIK, F. 100 years of Peter Drucker. 2009. Disponível em: <https://www.malikmanagement.com/en/pdf/ml/malik-letter-english-100-years-of-peter-drucker-11-2009.pdf >. Acesso em 12 jun. 2013.

MARCUSE, H. Ideologia da sociedade industrial. Rio de Janeiro: Zahar, 1967. 
MARCUSE, H. O fim da utopia. São Paulo: Paz e Terra, 1969.

MARCUSE, H. Um ensaio para a libertação. Lisboa: Bertrand, 1977.

MARCUSE, H. Razão e revolução. São Paulo: Paz e Terra, 2004.

MARINI, R. M. Dialéctica de la dependencia. México, D. F.: Era, 1973.

MARX, K. Manuscritos econômico-filosóficos. São Paulo: Martin Claret, 2005.

MARX, K. Grundrisse: manuscritos econômicos de 1857-1858 - esboços da crítica da economia política. Campinas: Boitempo, 2011.

MARX, K. Economic manuscripts of 1861-63. 2013a. Disponível em: <http://www.marxists.org/archive/marx/works/cw/volume30/index.htm>. Acesso em: 24 dez.

MARX, K. O capital: crítica da economia política. Livro I. São Paulo: Boitempo, 2013b.

MENDIETA, E. Introducctión - Política en la era de la globalización: crítica de razón política de E. Dussel. In: DUSSEL, E. Hacia una filosofía política crítica. Barcelona: Desclée de Brouwer, 2001. 15-39 p.

MISOCZKY, M. C. Sobre o centro, a crítica e a busca da liberdade na práxis acadêmica. Cadernos EBAPE.BR, v. 4, n. 3, p. 1-13, 2006.

MISOCZKY, M. C. Das práticas não-gerenciais de organizar à organização para a práxis da libertação. In: MISOCZKY, M. C.; FLORES, R. K.; MORAES, J. (Orgs.). Organização e praxis libertadora. Porto Alegre: Dacasa, 2010. $13-56$ p.

MISOCZKY, M. C. World visions in dispute in contemporary Latin America. Organization, v. 18, n. 3, p. 345-363, 2011.

MISOCZKY, M. C. In defense of life: the oppressed against mega-mining in Argentina. VIII Critical Management Studies International Conference, Manchester, julho 2013b. (Uma versão revisada deste texto fará parte do livro The Companion to Ethics and Politicis of Organization, organizado por Carl Rhodes e Allison Pullen, a ser publicado em 2014.)

MISOCZKY, M. C.; AMANTINO-DE-ANDRADE, J. Uma crítica à crítica domesticada nos estudos organizacionais. Revista de Administração Contemporânea, v. 9, n. 1, p. 193-212, 2005.

MISOCZKY, M. C.; BÖHM, S. Resistindo ao desenvolvimento neocolonial: a luta do povo de Andalgalá contra projetos megamineiros. Cadernos EBAPE.BR, v.11, n. 2, p. 311-339, $2013 \mathrm{a}$.

MISOCZKY, M. C.; FLORES, R. K.; GOULART, S. An anti-management statement in dialogue with critical Brazilian Organization Studies authors. Submetido à chamada de trabalhos "Challenging Anglo-Saxon dominance in Management and Organizational Knowledge" - aceito para publicação na Revista de Administração de Empresas em 2014.

OSTDICK, H. Peter Drucker: the father of management. Disponível em: <http://www.success.com/articles/1115peter-drucker-the-father-of-management-theoryComments>. Acesso em 12 jun. 2013.

PARKER, M. Utopia and the organizational imagination: eutropia. In: PARKER; M. (Ed.). Utopia and organization. Oxford. Blackwell, 2002. 217-224 p.

QUIJANO, A. Colonialidad y modernidad-racionalidad. In: BONILLA, H. (Ed.) Los conquistados: 1492 y la población indígena de las Américas. Quito: Tercer Mundo, 1992. 437-447 p.

QUIJANO, A. José Carlos Mariátegui y Europa: el otro lado del descubrimiento. Lima: Empresa Editora Amauta, 1993. 
RAMA, A. La novela latinoamericana 1920-1980. Bogotá: Procultura, 1982.

RICOEUR, P. História e verdade. Rio de Janeiro: Forense, 1968.

SALAZAR BONDY, A. ¿Existe una filosofía de nuestra América? México, D. F.: Siglo XXI, 1969.

SANTOS; T. A teoria da dependência. Rio de Janeiro: Civilização Brasileira, 2000.

SILVA, H. R. Fragmentos da história intelectual: entre questionamentos e perspectivas. Campinas: Papirus, 2002.

SILVA, R. História intelectual e teoria política. Revista de Sociologia Política, v. 17, n. 34, p. 301-318, 2009.

SLEMON, S. The scrumble of post-colonialism. In: ASHCROFT, B.; GRIFFITHS, G.; TIFFIN, H. (Eds.). The postcolonial reader. London: Routledge, 1994. 51-58 p.

SPINOZA, B. Tratado teológico-político. São Paulo: Martins Fontes, 2008.

SPIVAK, G. C. Can the subaltern speack? In: GROSSBERG, L; NELSON, C. (Eds.). Marxism and the interpretation of culture. Champagne: University of Illinois Press, 1988. 271-313 p.

SPIVAK, G. C. The post-colonial critic: interviews, strategies, dialogues. London: Routledge, 1990.

STARBUCK, P. Peter Drucker: the father of modern management. Disponível em: <http://www.mbsportal.bl.uk/taster/subjareas/busmanhist/mgmtthinkers/druckerprofile.aspx>. Acesso em 12 jun. 2013.

TRAGTENBERG, M. Administração, poder e ideologia. São Paulo: Moraes, 1980.

WEBER, M. Economía y sociedad. México, D.F.: Siglo XXI, 1997.

ZEA, L. La filosofía latinoamericana como filosofía sin más. México, D. F.: Siglo XXI, 1969.

ZIMMERMANN, M. A revolução nicaraguense. São Paulo: UNESP, 2006. 